\title{
Systematic Review \\ Upper Airway Changes in Diverse Orthodontic Looms: A Systematic Review and Meta-Analysis
}

\author{
Haytham Jamil Alswairki ${ }^{1,+}{ }^{\mathbb{D}}$, Mohammad Khursheed Alam ${ }^{2, *}+\mathbf{D}^{\mathbb{D}}$, Shaifulizan Ab Rahman ${ }^{3, *}$, \\ Rayan Alsuwailem ${ }^{2,4}$ and Sarah Hatab Alanazi ${ }^{5}$
}

check for

updates

Citation: Alswairki, H.J.; Alam, M.K.;

Rahman, S.A.; Alsuwailem, R.;

Alanazi, S.H. Upper Airway Changes

in Diverse Orthodontic Looms: A

Systematic Review and

Meta-Analysis. Appl. Sci. 2022, 12,

916. https://doi.org/10.3390/

app12020916

Academic Editors: Andrea Scribante and Rosa Valletta

Received: 12 November 2021

Accepted: 12 January 2022

Published: 17 January 2022

Publisher's Note: MDPI stays neutral with regard to jurisdictional claims in published maps and institutional affiliations.

Copyright: () 2022 by the authors. Licensee MDPI, Basel, Switzerland. This article is an open access article distributed under the terms and conditions of the Creative Commons Attribution (CC BY) license (https:// creativecommons.org/licenses/by/ $4.0 /)$.
1 Orthodontic Unit, School of Dental Sciences, Universiti Sains Malaysia, Kota Bharu 16150, Kelantan, Malaysia; hitham.swerki@gmail.com

2 Orthodontics, Preventive Dentistry Department, College of Dentistry, Jouf University, Sakaka 72345, Saudi Arabia; rayan.alswilem@jodent.org

3 Oral and Maxillofacial Surgery Department, School of Dental Sciences, Universiti Sains Malaysia, Kota Bharu 16150, Kelantan, Malaysia

4 Department of Oral Diagnostic Science, School of Dental Medicine, University at Buffalo, New York, NY 14226, USA

5 College of Dentistry, Jouf University, Sakaka 72345, Saudi Arabia; sara.alanazi@jodent.org

* Correspondence: mkalam@ju.edu.sa or dralam@gmail.com (M.K.A.); shaiful@usm.my (S.A.R.)

+ Authors contributed equally and both are the 1st author.

\begin{abstract}
Upper airway assessment is particularly important in the daily work of orthodontists, because of its close connection with the development of craniofacial structures and with other pathologies such as Obstructive Sleep Apnea Syndrome (OSAS). Three-dimensional cone-beam computed tomography images provide a more reliable and comprehensive tool for airway assessment and volumetric measurements. However, the association between upper airway dimensions and skeletal malocclusion is unclear. Therefore, the current systematic review evaluates the effects of different surgical movements on the upper airway. Materials and Methods: Medline (PubMed, OVID Medline, and EBSCO), Cochrane Library (Cochrane Review and Trails), Web of Knowledge (social science, and conference abstracts), Embase (European studies, pharmacological literature, and conference abstracts), CINAHL (nursing and allied health), PsycInfo (psychology and psychiatry), SCOPUS (conference abstracts, and scientific web pages), and ERIC (education) databases were searched. Two authors independently performed the literature search, selection, quality assessment, and data extraction. Inclusion criteria encompassed computed tomography evaluations of the upper airway spaces with retrospective, prospective, and randomised clinical trial study designs. To grade the methodological quality of the included studies a GRADE risk of bias tool was used. Results and conclusion: In total, 29 studies were included. Among these, 17 studies had a low risk of bias, whereas 10 studies had a moderate risk of bias. A meta-analysis was performed with the mean differences using a fixed-effects model. Heterogeneity was assessed with the Q-test and the $\mathrm{I}^{2}$ index. The meta-analysis revealed significant ( $p \leq 0.001,95 \%$ confidence interval) increases in upper airway volume after rapid maxillary expansion and surgical advancement for the correction of Class II.
\end{abstract}

Keywords: airway; orthodontics; extraction; expansion; protraction; surgery

\section{Introduction}

The human upper airway could be defined as the airway space extending from the nose's nares and the mouth's stoma down to the cricoid cartilage in the larynx. The nasal and oral cavities merge in the area known as the pharynx, which is divided anatomically into three sections: the nasopharynx, oropharynx, and hypopharynx.

The shape and dimensions of the upper airway passages influence the volume of air passing through them. The close anatomical relationship between the upper airway and the 
craniofacial and dental structures dictates their influence on each other. The normal growth and development of craniofacial structures depend on a patent airway and nasal breathing.

Orthodontists have long been interested in airway analysis because of the airway's potential importance to the normal development of the craniofacial region as well as its involvement in the diagnosis and treatment of mouth breathing and sleep disorders. Clinicians need to evaluate the upper airway objectively and identify the normal and abnormal anatomical boundaries and dimensions. Although two-dimensional lateral cephalograms have been used for decades to evaluate the airway's shape, size, position, and relationship with other anatomical structures, they lack the information to illustrate the anatomically complex airway structure in three dimensions. Lateral cephalograms could be used as an initial screening method for airway evaluation, but three-dimensional conebeam computed tomography (CBCT) images provide a more reliable and comprehensive tool for airway assessment and volumetric measurements. The findings of snoring and interrupted sleep together with diagnostic images obtained during the dental examination can provide indications of possible airway disorders and support the need for referral to a medical specialist referral.

Nasal obstruction and its inseparable companion, "mouth breathing," have been assumed to affect dentofacial growth in the current literature. Although some researchers have found no association between the adequacy of the airway and dentofacial morphology [1]. It seems to be a consensus that the oropharyngeal (OP) and nasopharyngeal structures play roles in the development of the dentofacial complex [2].

The etiology of malocclusions is believed to be multifactorial, and it could be considered erroneous to associate malocclusions with only breathing mode. Because the airway is assumed to play a role in dentofacial development, several studies have attempted to correlate patients with normal naso-respiratory functions with different malocclusions and airway dimensions.

Despite this, the relationship between upper airway dimensions and skeletal malocclusion remains controversial. Some studies have shown no effect on the airway after orthodontic treatment [3], whereas others have reported a change in the airway [4]. The controversy regarding these outcomes might be related to the heterogeneity in the included articles, types of malocclusions, and imaging methods.

In addition, there has been no meta-analysis published in the literature that has compared changes in the airway dimensions resulting from different types of orthodontic treatment by using cone-beam computed tomography (CBCT), a 3D imaging technique, and only one single meta-analysis that included a small number of studies [5]. Previous systematic reviews [5-8] have investigated this subject based on data from only twodimensional images.

Therefore, the present meta-analysis focused only on studies that used computed tomography (CT) for airway evaluation, particularly CBCT. Through a meta-analysis, this study aims to assemble scientific evidence related to the effects of orthodontic treatment modalities on airway space.

\section{Materials and Methods}

The systematic review is constructed in accordance with the Preferred Reporting Items for Systematic Reviews and Metanalyses standards of quality for the planning, conducting, and reporting of systematic reviews and meta-analyses [9]. A search protocol was specified in advance and registered at PROSPERO (International Prospective Register of Systematic Reviews ID CRD42020180936).

Participants, Interventions, Control and Outcomes (PICO) question.

To better outline the study, the participants, interventions, control and outcomes (PICO) format was followed (Table A1). 


\subsection{Search Strategy for the Identification of Studies}

We performed a database search that included Medline (PubMed, OVID Medline, and EBSCO), Cochrane Library (Cochrane Review, Trails), Web of Knowledge (social science, and conference abstracts), Embase (European studies, pharmacological literature, and conference abstracts), CINAHL (nursing and allied health), PsycInfo (psychology and psychiatry), SCOPUS (conference abstracts, and scientific web pages), and ERIC (education). We used a specific search strategy with the following focused key terms: (airway OR oropharyngeal OR pharyngeal) AND ((orthodontic AND extraction) OR (Orthodontic AND Expansion)) OR ((Orthodontic AND ORTHOGNATHIC SURGERY)) OR ((Orthodontic AND Non-Extraction)) OR ((Orthodontic AND Distalization)) OR ((Orthodontic AND Expansion)) OR ((Orthodontic AND Cleft)) OR ((Orthodontic AND Functional Appliance)) OR ((Orthodontic AND Headgear)) OR ((Orthodontic AND Surgery)) OR (Orthodontic AND functionalization) OR (Orthodontic AND instrumentation) OR (Orthodontic AND surgical procedures) OR (Orthodontic AND oropharynx).

A gray literature search was performed using the following databases: Google Scholar, National Library of Medicine, and Social Science Research for Thesis. In addition, we searched four key orthodontic journals (Angle Orthodontics, American Journal of Orthodontics and Dentofacial Orthopedics, Journal of Clinical Orthodontics, and European Journal of Orthodontics) using their table of contents for relevant articles. The article search was performed up to November 2021.

\subsection{Study Selection Procedure}

Two authors independently reviewed all studies. Titles and abstracts were first screened to exclude irrelevant articles. Full texts of the remaining studies were further evaluated on the basis of preset selection criteria. Discrepancies between the two reviewers were addressed by a discussion with a third author. Final decisions were made after a consensus was reached. The selection of articles for inclusion in this review was based on the following criteria: human clinical trials with a prospective or retrospective design children or adult patients submitted to orthodontic treatment measurement of OP airway via CT before and after treatment and articles in English. The exclusion criteria were case reports, review articles, editorials, or opinions, and patients with a syndromic cleft.

\subsection{Data Extraction}

Data were extracted independently by two reviewers, using a specially designed data extraction form. The following data were extracted: author, year of publication, country, age, sample size, study design, type of orthodontic intervention, methodology, mean results, and outcome.

\subsection{Risk of Bias Assessment}

The risk of bias assessment of the included studies was performed using the GRADE tool [10]. We developed a checklist for evaluating meta-analyses of RCTs for the purpose of informing a GRADE assessment. The checklist covers the main determinants for each of the five factors (risk of bias, inconsistency, indirectness, imprecision, and publication bias) that can lead to a downgrading of quality in the GRADE system. Table A2 summarised the domains used to determine the risk of bias using standardized criteria, the included studies were further classified for each domain as low risk, moderate risk, serious risk, and critical risk of bias. The experiments were comparable to well-performed randomised controlled trials, and the domain in question was considered to have a low risk of bias. The experiments that could not be compared with well-performed randomised studies but were sound within the domain of a nonrandomized trial were considered to have a moderate bias. Studies containing certain significant problems were classified as being at serious risk of bias. A critical risk of bias was classified as studies that were too problematic to provide any useful evidence on the effect of the intervention or that did not provide any 
information on the basis of the included of the 29 studies, 9 studies had a low risk of bias, 2 studies had a high risk of bias, and 18 studies had a moderate risk of bias.

\subsection{Meta-Analysis}

RevMan 5.3 analysis software (http:/ /ims.cochrane.org/revman (accessed on 11 January 2022)) was used for conducting the meta-analysis (Cochrane Collaboration, Copenhagen, Denmark). Data related to the Mean Difference (MD) from various studies were estimated using the inverse-variance method. Two-sided $95 \%$ confidence intervals $(95 \%$ CIs) were computed by using the fixed-effect model. The proportion of variability that attributes for heterogeneity was assessed via Cochran's Q-statistic and $\mathrm{I}^{2}$ statistics. A fixed-effects model was used when heterogeneity was low $\left(\mathrm{I}^{2}<50 \%\right)$ and, when $\mathrm{I}^{2}$ was $>50 \%$, a random-effects model was used. Funnel plots were employed for the detection of publication bias, and bias is revealed if the plots are asymmetrical. A value of $p<0.05$ was considered statistically significant. Sensitivity analysis was performed to evaluate the robustness of the meta-analysis by removing outliers from the analyses with publication bias.

\section{Results}

After screening the titles and abstracts of 102 unique papers, 66 potentially eligible articles were selected. Two researchers independently reviewed each title and abstract, and the obtained information was compared. Inter-examiner disagreements were resolved in a consensus meeting. Of the 66 potentially eligible articles, 37 were excluded. These articles were excluded for the following reasons: non-3D $(n=27)$ and systematic review and review articles $(n=15)$ (Figure 1).

\subsection{Included Studies}

A total of 29 articles were identified for inclusion in this review (Table A3). This systematic review was based on prospective and retrospective cross-sectional studies and controlled clinical trials.

\subsection{Study Characteristics}

Of the 29 included studies, 10 studies were performed in the United States, 5 were performed in China, 2 studies were published in each Australia, Brazil, Italy, and Turkey. Other studies were performed in Egypt, Korea, Minneapolis, Singapore, South Korea, and India. Among the included 29 studies in this review, 20 studies were retrospective studies, 6 studies were prospective studies and the remaining studies were controlled clinical studies, longitudinal study and Quasi-experimental study.

\subsection{Clinical Characteristics}

A total of 1012 patients were included in the study, with sample sizes ranging from 8 to 83. Female patients were dominant in this review. The majority of the included studies demonstrated the Class III malocclusion type of malocclusion $(n=9)$ followed by Class II malocclusion $(n=7)$ and Class I malocclusion $(n=9)$. Out of 29 studies included in this review, 27 studies were used CBCT for the assessment of airways. 


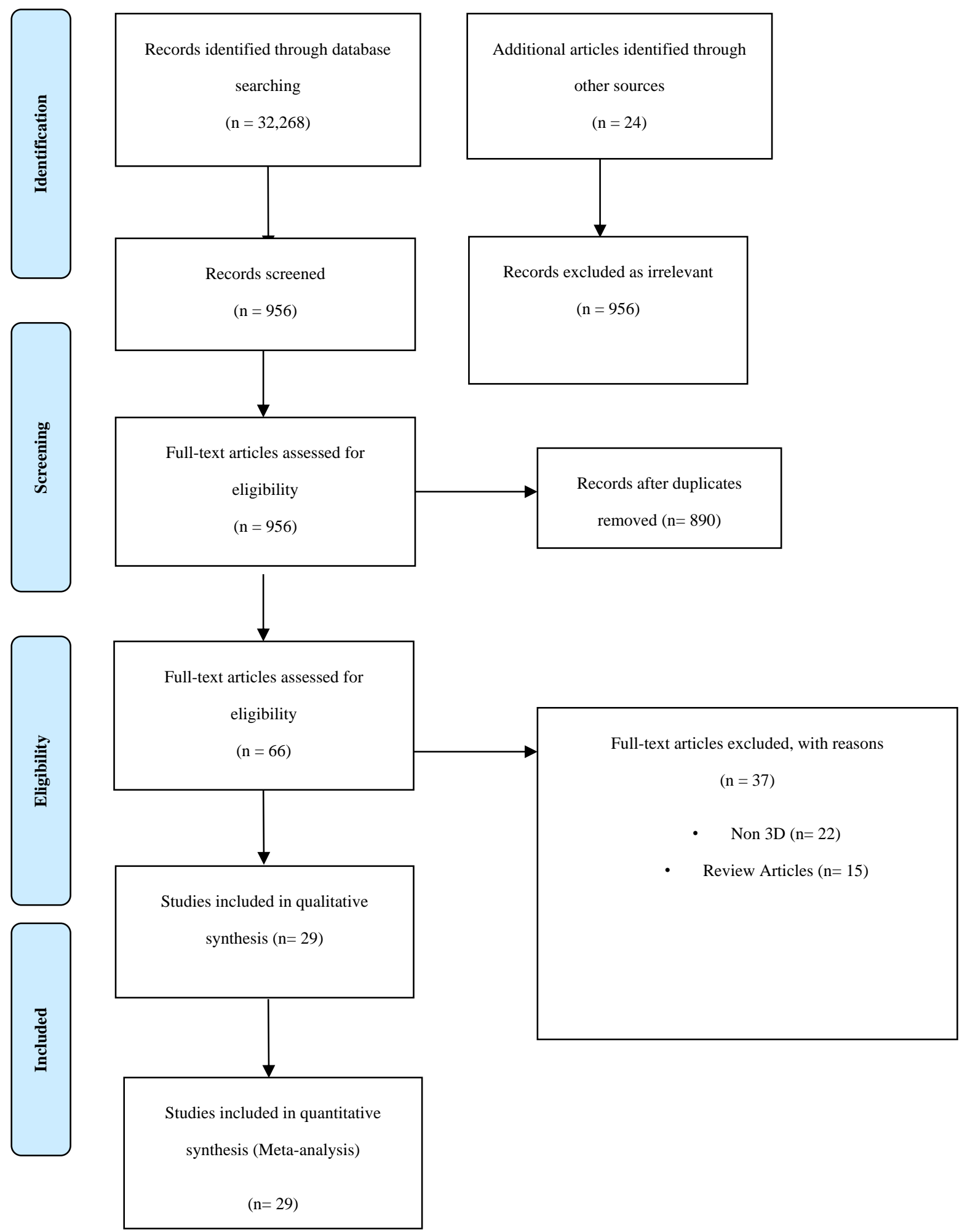

Figure 1. PRISMA flow diagram.

\subsection{Change in Airway Space}

\subsubsection{Expansion with Protraction}

Five studies report the Meta analysis for expansion with protraction between the experimental and control group. The pooled analysis showed a significant effect on expansion with protraction between the experiment and control group (MD = 0.78, CI-0.29,1.28; 
$\left.\mathrm{Chi}^{2}=9.01 ; \mathrm{I}^{2}=56 \%, p=0.002<0.05\right)$. Heterogeneity between the five studies is medium $\left(\mathrm{I}^{2}=56 \%\right)$. Test for overall effect: $\mathrm{Z}=3.12(p=0.002)$ (Figures 2 and 3$)$.

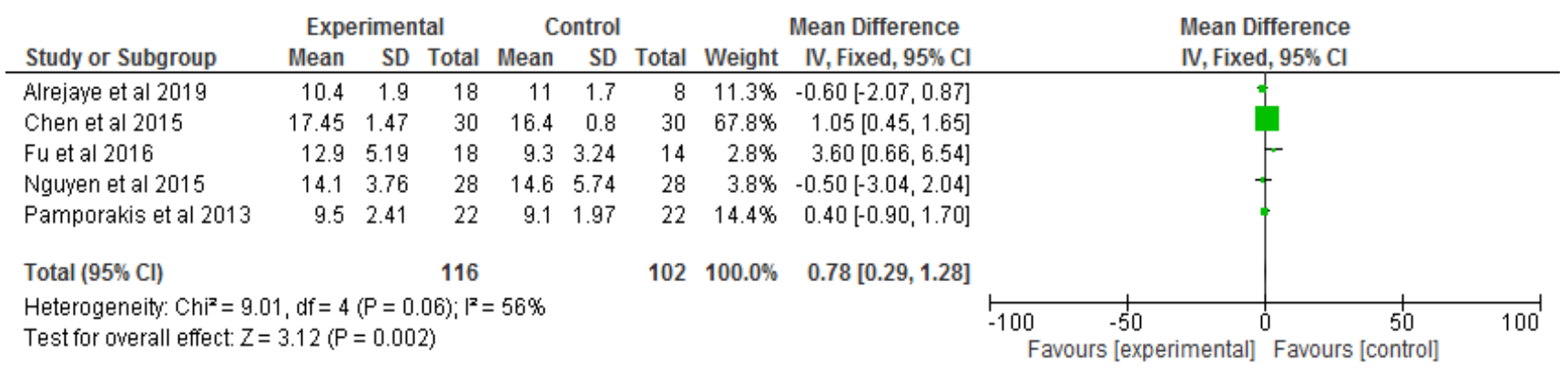

Figure 2. Forest plot for expansion with protraction between experiment and control.

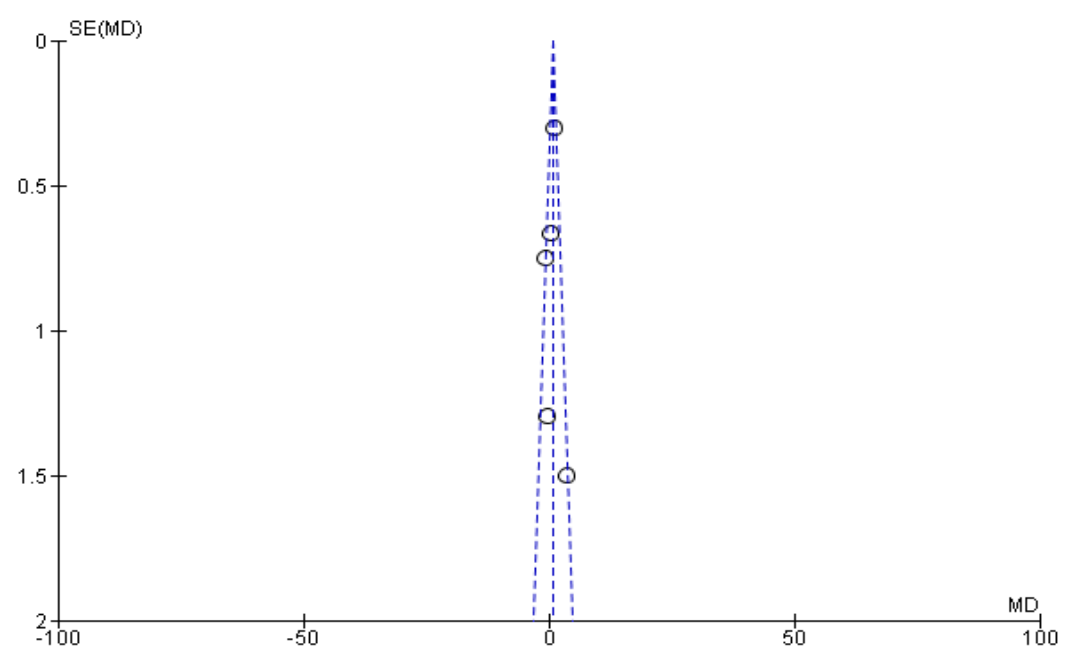

Figure 3. Funnel plot for expansion with protraction between experiment and control.

\subsubsection{Clean Aligner}

Two studies reported the Meta analysis for clear aligners between before and after treatment. The pooled analysis showed no effect on the clear aligner between before and after treatment $\left(\mathrm{MD}=1.57, \mathrm{CI}-0.56,3.71 ; \mathrm{Chi}^{2}=0.05 ; \mathrm{I}^{2}=0 \%, p=0.15>0.05\right)$. Heterogeneity between the two studies is low $\left(\mathrm{I}^{2}=0 \%\right)$. Test for overall effect: $\mathrm{Z}=1.44$ $(p=0.15)$ (Figures 4 and 5).

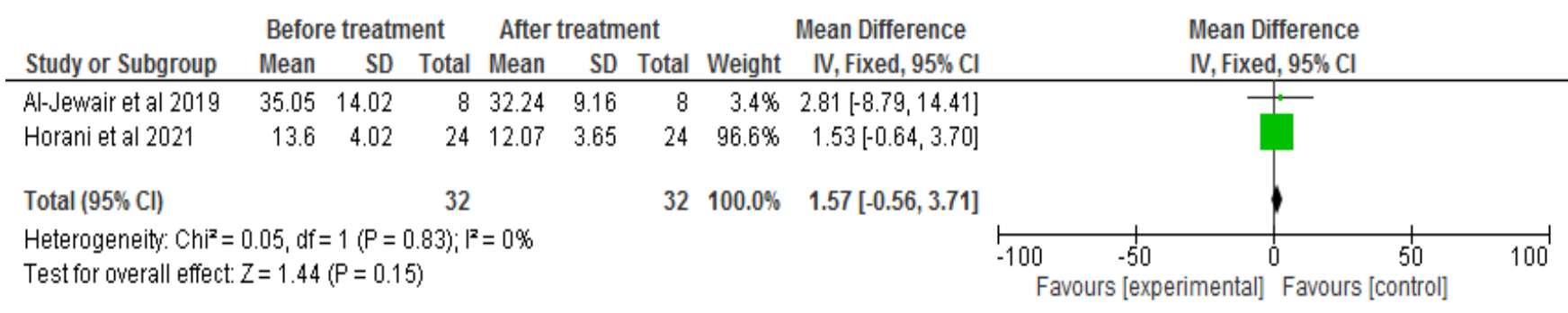

Figure 4. Forest plot for clear aligner between before and after treatment. 


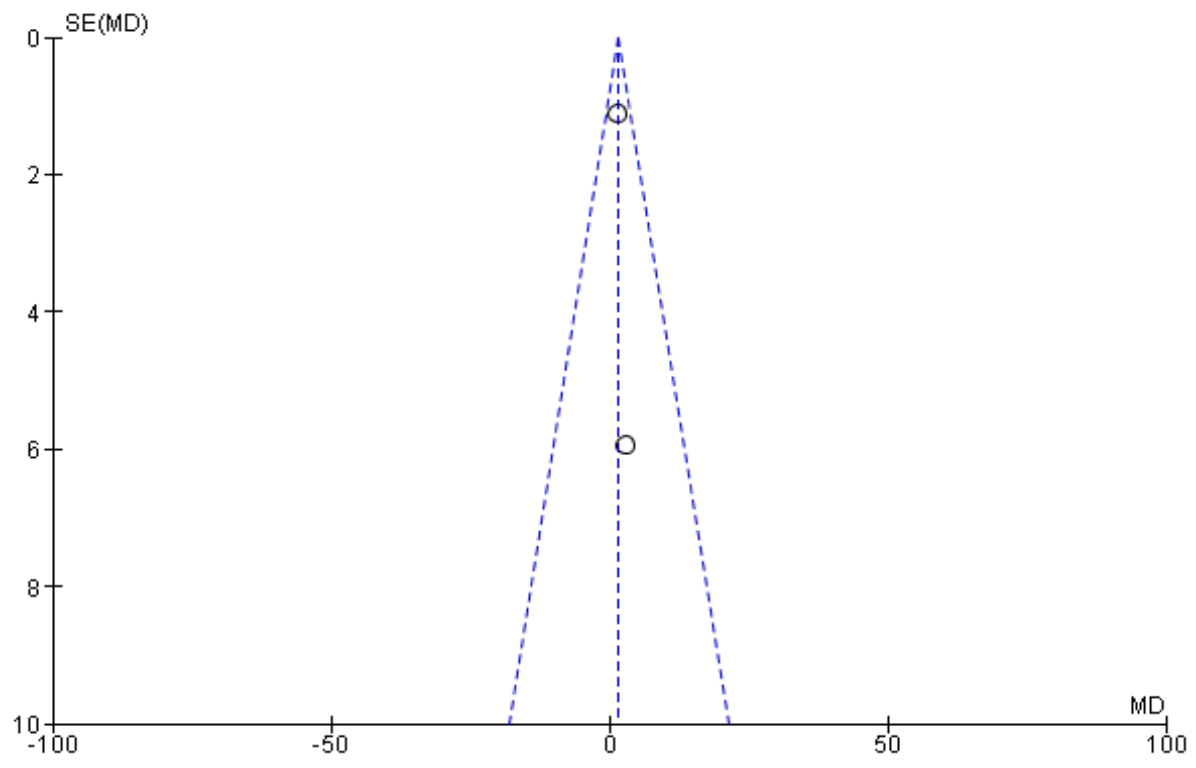

Figure 5. Funnel plot for clear aligner between before and after treatment.

\subsubsection{Extraction and Non-Extraction}

Five studies report the Meta analysis between extraction and non-extraction. The pooled analysis showed no effect on extraction and non-extraction (MD $=0.37, \mathrm{CI}-1.11,1.85$; $\left.\mathrm{Chi}^{2}=62.54 ; \mathrm{I}^{2}=94 \%, p=0.62>0.05\right)$. Heterogeneity between the five studies is high $\left(\mathrm{I}^{2}=94 \%\right)$. Test for overall effect: $\mathrm{Z}=0.49(p=0.62)$ (Figures 6 and 7$)$.

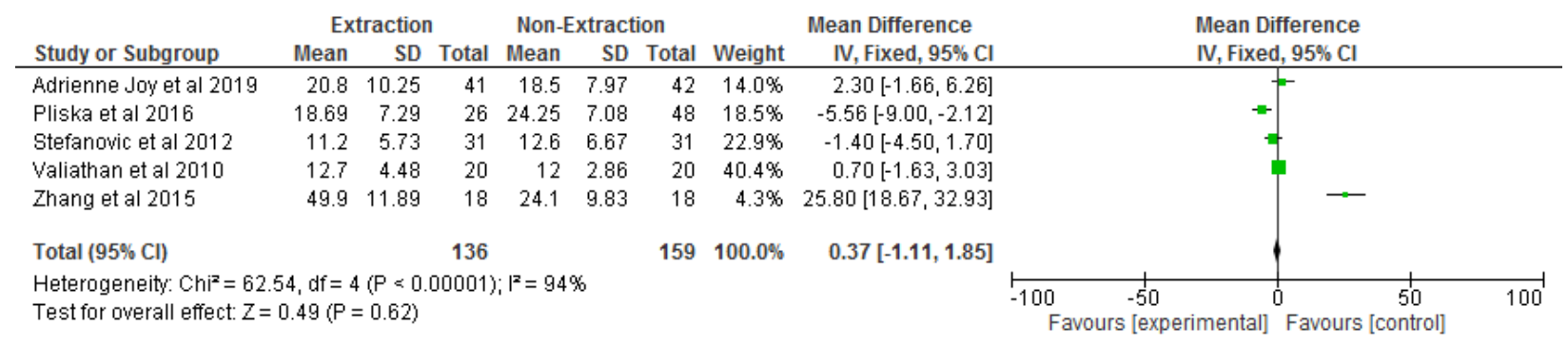

Figure 6. Forest plot for extraction and non-extraction.

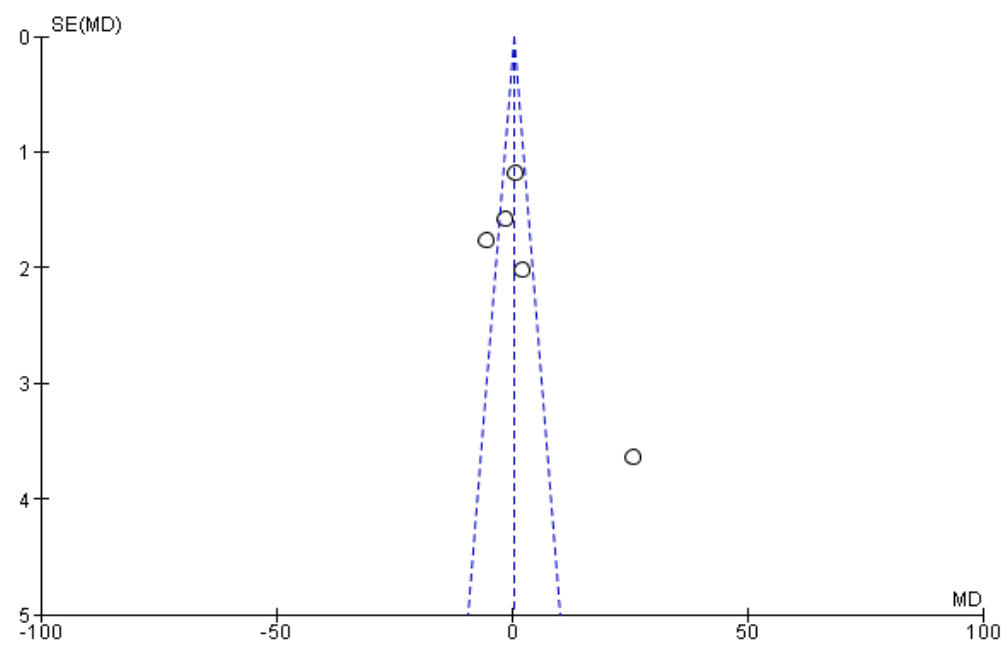

Figure 7. Funnel plot for extraction and non-extraction. 


\subsubsection{Functional Appliance}

Three studies report the Meta analysis for functional appliance between the experiment and control group. The pooled analysis showed a significant effect on functional appliance between the experiment and the control group $\left(\mathrm{MD}=2.54, \mathrm{CI} 1.17,3.90 ; \mathrm{Chi}^{2}{ }^{2}=10.27\right.$; $\left.\mathrm{I}^{2}=81 \%, p=0.0003\right)$. Heterogeneity between the three studies is high $\left(\mathrm{I}^{2}=81 \%\right)$. Test for overall effect: $Z=3.64(p=0.0003)$ (Figures 8 and 9$)$.

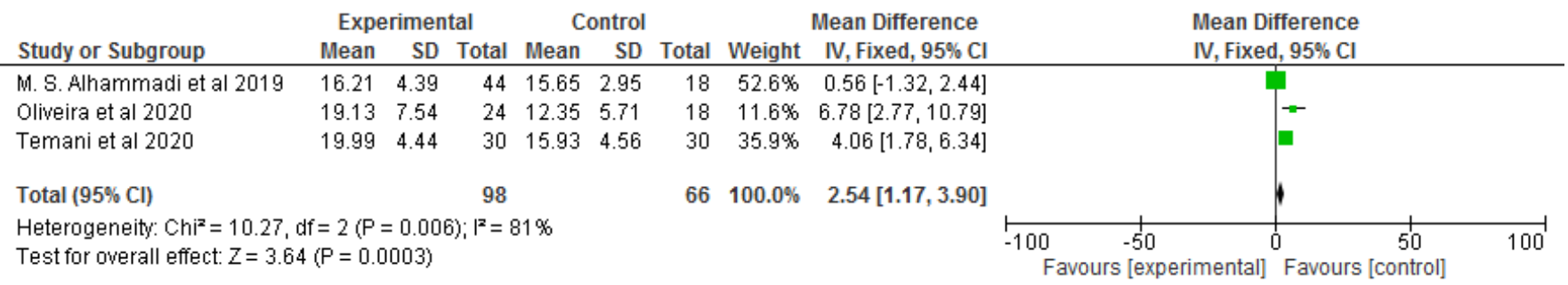

Figure 8. Forest plot for functional appliance between experiment and control.

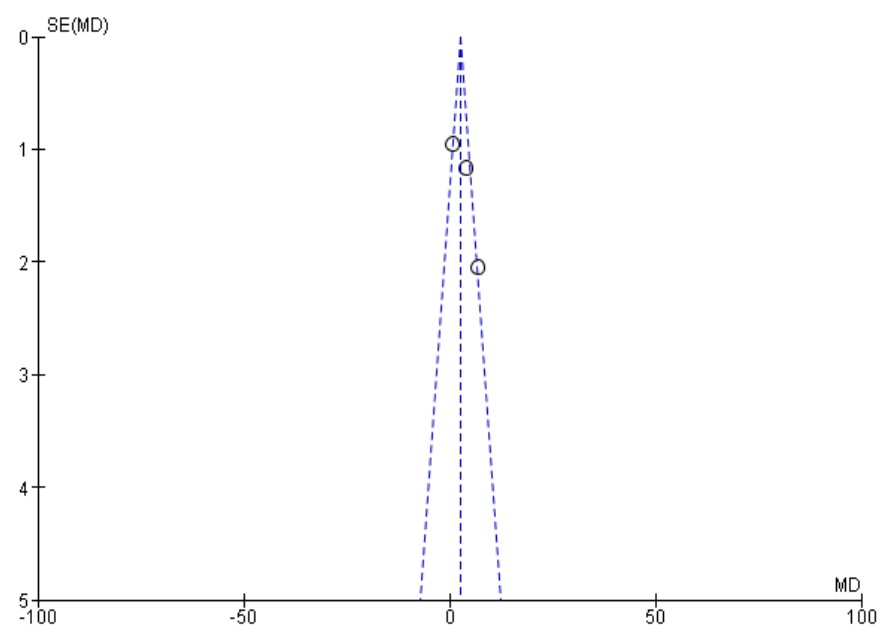

Figure 9. Funnel plot for functional appliance between experiment and control.

\subsubsection{Maxillary Expansion}

Eight studies report the Meta analysis for maxillary expansion between the experiment and control group. The pooled analysis showed a significant effect on maxillary expansion between the experiment and control group $\left(\mathrm{MD}=-1.94, \mathrm{CI}-2.44,-1.43 ; \mathrm{Chi}^{2}=588.08\right.$; $\left.\mathrm{I}^{2}=99 \%, p<0.0001\right)$. Heterogeneity between the eight studies is high $\left(\mathrm{I}^{2}=99 \%\right)$. Test for overall effect: $Z=7.47$ ( $p=0.0001$ ) (Figures 10 and 11).

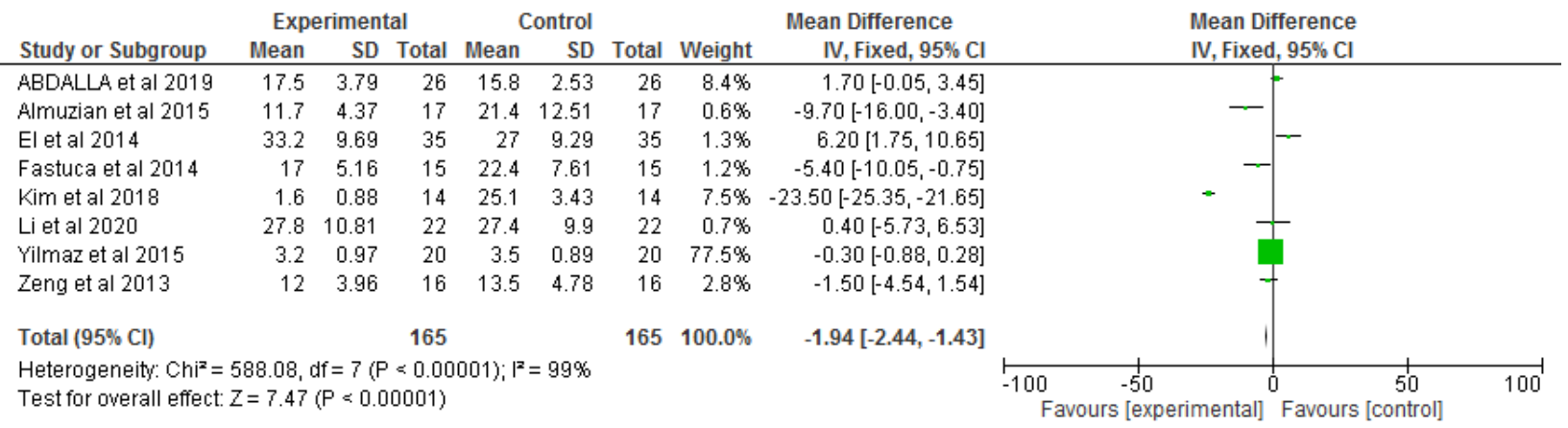

Figure 10. Forest plot for maxillary expansion between experiment and control. 


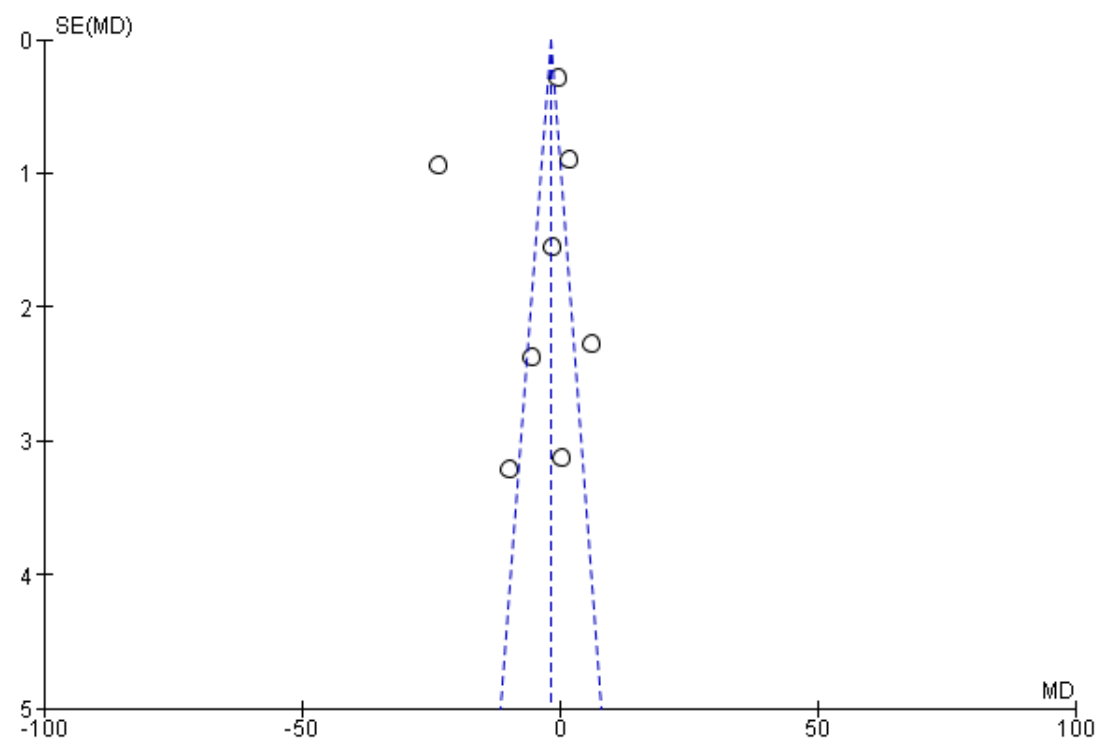

Figure 11. Funnel plot for maxillary expansion between experiment and control.

\subsubsection{Surgery Class III}

Three studies report the Meta analysis for surgery class III between the pre- and post-surgical group. The pooled analysis showed a significant effect on surgery class III between the pre- and post-surgical group ( $\mathrm{MD}=3.45, \mathrm{CI} 2.54,4.35 ; \mathrm{Chi}^{2}=7.60 ; \mathrm{I}^{2}=74 \%$, $p<0.0001)$. Heterogeneity between the three studies is high $\left(\mathrm{I}^{2}=74 \%\right)$. Test for overall effect: $Z=7.48(p=0.0001)$ (Figures 12 and 13).

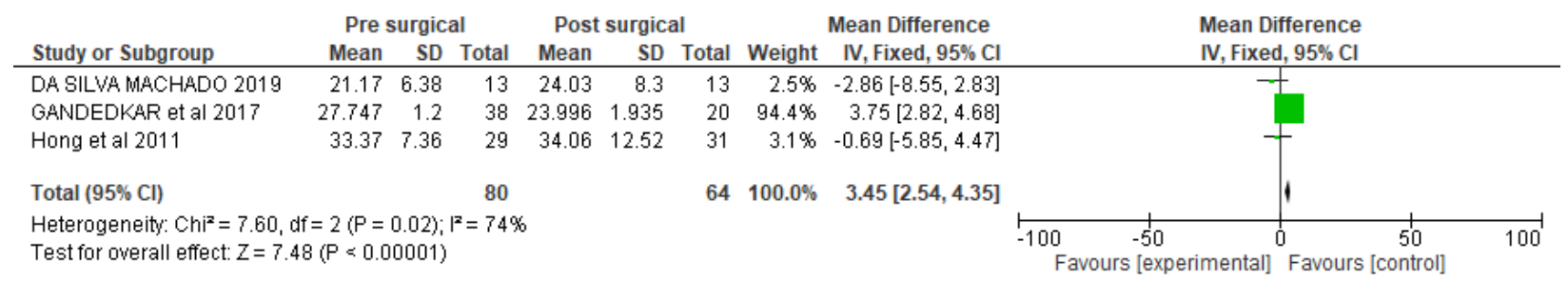

Figure 12. Forest plot for Surgery class III between pre and post surgery.

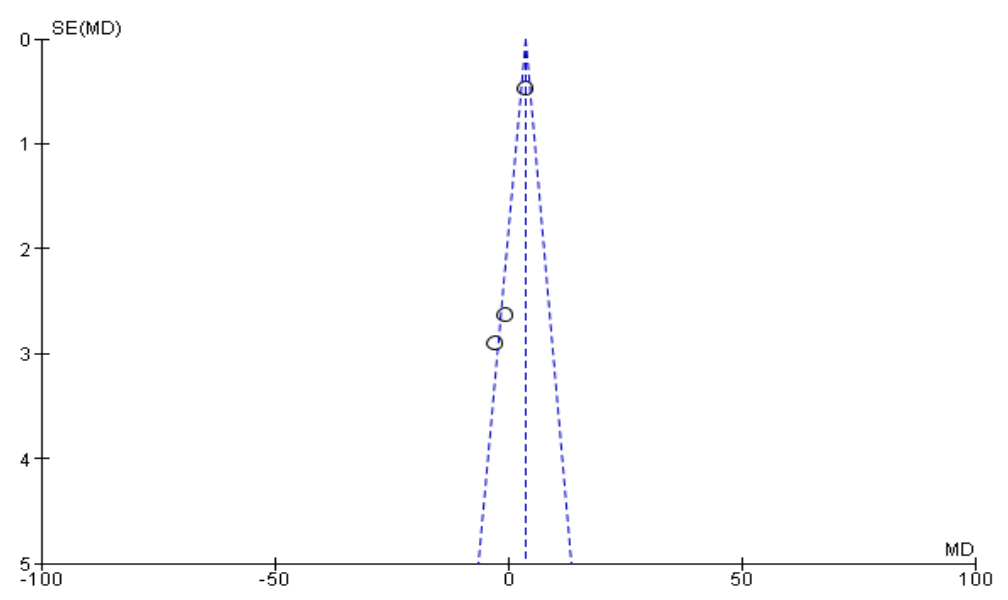

Figure 13. Funnel plot for Surgery class III between pre and post surgery.

\subsection{Sensitivity Analysis}

\subsubsection{Extraction and Non-Extraction}

Two studies [11,12] lies outside the funnel, so removing the studies and rerunning the analysis we get three studies that report the Meta analysis between extraction and 
non-extraction. The pooled analysis showed no effect on extraction and non-extraction $\left(\mathrm{MD}=0.37, \mathrm{CI}-1.32,2.05 ; \mathrm{Chi}^{2}=2.25 ; \mathrm{I}^{2}=11 \%, p=0.67>0.05\right)$. Heterogeneity between the five studies is low $\left(\mathrm{I}^{2}=11 \%\right)$. Test for overall effect: $\mathrm{Z}=0.43(p=0.67)$ (Figures 14 and 15).

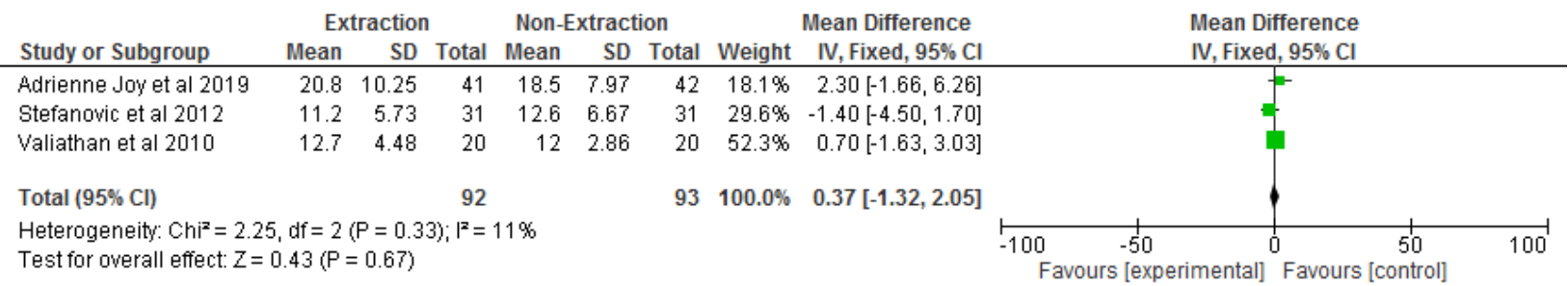

Figure 14. Forest plot for extraction and non-extraction after removing the studies lies outside the funnel.

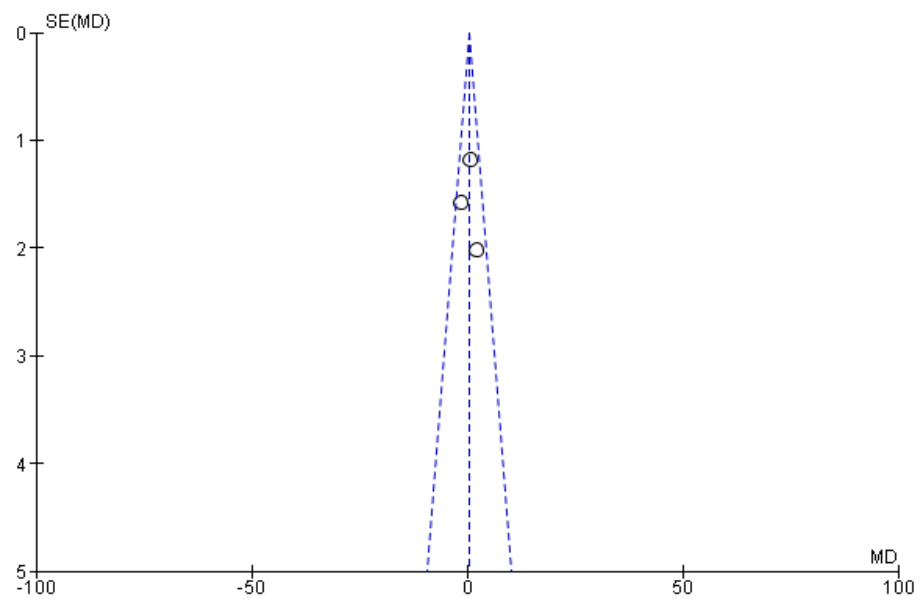

Figure 15. Funnel plot for extraction and non-extraction after removing the studies lies outside the funnel.

\subsubsection{Maxillary Expansion}

Four studies [4,13-15] lie outside the funnel, so removing the studies and rerunning the analysis we get four studies that report the Meta analysis for maxillary expansion between experiment and control group. The pooled analysis showed no effect on maxillary expansion between experiment and control group $\left(\mathrm{MD}=-0.14, \mathrm{CI}-0.68,0.39 ; \mathrm{Chi}^{2}=5.33\right.$; $\left.\mathrm{I}^{2}=44 \%, p=0.60>0.05\right)$. Heterogeneity between the four studies is low $\left(\mathrm{I}^{2}=44 \%\right)$. Test for overall effect: $Z=0.53(p=0.60)$ (Figures 16 and 17).

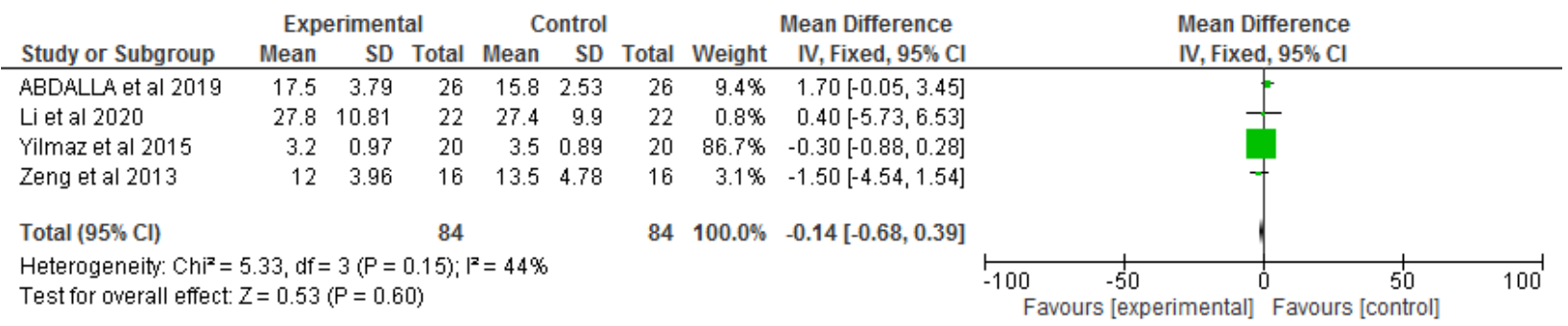

Figure 16. Forest plot for maxillary expansion between experiment and control after removing the studies lies outside the funnel. 


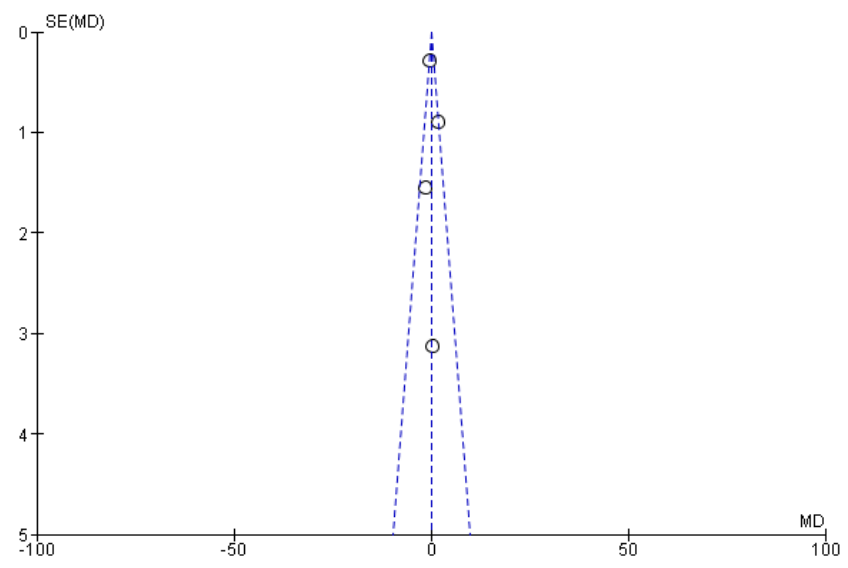

Figure 17. Funnel plot for maxillary expansion between experiment and control after removing the studies lies outside the funnel.

\section{Discussion}

Respiratory function has a considerable influence on the development of the craniofacial complex, and the upper airway assessment has been an important concern for the orthodontist while performing different modalities of the management of dental and skeletal malocclusion [2]. Controversies exist regarding the influence of orthodontic treatment on the upper airway; hence we undertook this systematic review. Twenty-seven studies were found to be appropriate for inclusion in this review, and the methodological quality of most of the studies was acceptable which permitted quantitative synthesis. The effects on the airway were assessed with orthopaedic protraction, rapid maxillary expansion, myofunctional appliances, fixed orthodontic therapy with extraction, and orthognathic surgery for correction of skeletal Class II and Class III malocclusion.

Randomised controlled trials provide the highest level of evidence. However, wellconducted observational studies also contribute meaningful evidence to the existing scientific knowledge, especially when randomised clinical trials are unethical or unfeasible [16]. Because there were not enough randomised studies that evaluated the airway after different modalities of orthodontic treatment, prospective, and retrospective observational studies were also included in this review.

Airway dimensions are assessed by various means including lateral cephalograms, and CBCT. Although the pharyngeal airway is a 3-D structure. Conventional lateral cephalography provides only the sagittal and vertical dimensions and thus has limited value for an accurate assessment. The transverse dimension of the airway has been found to be variable for a similar area of the nasopharyngeal airway, which raises concerns over the conclusions drawn from the lateral head film [17]. Thus, it would be more accurate to provide a 3-D analysis of the airway assessment and this review included studies evaluating the 3-D volume of the airway after the use of various orthodontic treatment approaches.

Rapid maxillary expansion, introduced in the 19th century, is routinely performed for the correction of posterior crossbite and the creation of space to relieve crowding. This technique is now believed to be helpful for additional purposes, such as reduction of nocturnal enuresis [18], improvement of impaired nasal respiration [19], and relief from obstructive sleep apnoea [20]. This review identified eight studies that assessed the impact of rapid palatal expansion on the airway where all of them were found to have significant improvements except for the study by El et al. [4] and Abdalla et al. [21]. The combined analysis showed a significant improvement in the upper airway, which is similar to the findings reported by Buck et al. [22] in their 2017 systematic review. The mean age of the patient was higher in the studies by Kim et al. [15] and Li et al. [23] and those authors used implant-supported maxillary expansion in contrast to other studies in which tooth-supported expanders were used in adolescents.

For managing skeletal class III malocclusion, retrognathic maxilla expansion in combination with protraction is indicated for growth modulation. This modality has recently 
received increased attention as several studies have suggested improvement in the airway dimension facilitating the management of obstructive sleep apnoea $[15,20,24]$. Separation of the midpalatal suture decreases the resistance of the circummaxillary sutures and subsequent protraction initiates the cellular response resulting in the forward and downward movement of the maxillary complex [25]. This review included five observational studies that assessed the effect of maxillary expansion and protraction on the airway. All of the studies were retrospective except the study by Fu et al. [26] which had a prospective study design. Fu et al. [26] and Alrejaye et al. [3] enrolled cleft patients, whereas noncleft subjects were evaluated in the other studies. The pharyngeal anatomy of cleft patients was found to be different from the noncleft children and there was a varying effect of skeletal protraction among the cleft patients as compared with non-cleft patients [27]. Only the study by $\mathrm{Fu}$ et al. [26] showed a significant increase in the pharyngeal airway volume after expansion and protraction, however, this difference was insignificant when combined with the data from other studies. In contrast, the systematic review by Lee et al. [5] found a significant increase in the upper airway after rapid maxillary expansion and protraction with nonsignificant changes in the lower airway when assessed on two-dimensional lateral cephalogram.

The extraction of one or more teeth is frequently indicated in contemporary orthodontics for the management of various dentoskeletal problems. Premolars are most often extracted for crowding correction and retraction of anteriors which can result in a considerable number of changes in the hard and soft tissues of the dentofacial region [28]. Distal movement of the incisors could lead to the encroachment of space with posterior displacement of the tongue narrowing the upper airway. In this review, we identified Five observational studies that assessed the upper airway after the extraction of premolars and the retraction of anteriors. All the studies were retrospective and compared airway changes after orthodontic treatment in patients with and without extraction of at least two premolars. Studies by Stefanovic et al. [29] and Valiathan et al. [30] included adolescent patients, whereas the other three studies included adult patients ( $>18$ years). During the period of active craniofacial growth (i.e., 8 to 18 years of age), the length and volume of the airways increase. Thus, in adolescents' treatment effect, if any, can be compensated by the growth of tissues surrounding the airway in adolescents [31]. In this review, none of the included studies reported a significant volumetric change in the upper airway, and the results of the pooled analysis were inconclusive. The hyoid bone was displaced backward and downward with a large incisor retraction [32] and the evidence varies on its effect on the airway $[33,34]$. Only the study by Zhang et al. [12] reported a change in the position of the hyoid bone in which the displacement was not statistically significant.

A posteriorly positioned mandible is commonly associated with obstructive sleep apnoea [35] and its advancement is believed to facilitate an increase in the upper airway volume which mitigates the apnoea [36]. Functional appliances enhance the growth of the mandible by repositioning it anteriorly, however, recent evidence suggests that the advancement consists of dentoalveolar changes with only minimal skeletal changes [37,38]. We identified three studies measuring the volumetric changes in the airway after functional appliances in growing Class II patients with mandibular retrusion. Among all the studies, airway volume immediately after the treatment was compared with the pretreatment values, we conclude the effects on long-term changes could not explore the effect on long-term changes. The studies varied in the type of appliances used: Oliveira et al. [39] used Herbst appliance, Temani et al. [40] studied on Forsus, and Alhammadi et al. [41] compared removable twin block and Forsus with the control group. All studies reported a significant improvement in the upper airway except for the Forsus group in the study by Alhammadi et al. [41] in which insignificant changes were noticed. The pooled analysis revealed an insignificant increase in the airway volume which is in contrast with the result of the meta-analysis by Xiang et al. [42], who found a significant increase in the airway dimension at the OP region as measured with a cephalogram. In the systematic review by Kannan et al. [43] in which most of the included studies used lateral cephalogram, the use 
of twin block induced significant changes in the airway volume at the nasopharynx, and hypopharynx, however, no such improvement was observed with the Herbst.

A retrognathic maxilla and mandible can compromise the upper airway volume and are associated with obstructive sleep apnoea $[35,44,45]$. Orthognathic surgery involves the manipulation of the jawbones in which their position is changed from the surrounding craniofacial structures. This may cause morphological alteration of the airway resulting in further respiratory complications such as obstructive sleep apnea. However, there is conflicting evidence on the effects of this surgery on the airway [46,47]. This review identified six studies, three each for skeletal Class II and Class III malocclusion treated by means of orthognathic surgery. Da Silva Machado et al. [48] found an overall increase in the upper airway after bimaxillary surgery in Class III which contradicts the findings by Gandedkar et al. [49] who noticed a decrease in the oropharynx volume without any change in the STOP-BANG score. The pooled analysis showed a significant decrease in the upper airway after orthognathic surgery for skeletal Class III malocclusion. All included studies for surgical Class II correction found a significant increase in the airway volume. Similarly, in their systematic reviews, Christovam et al. [50] Hernando et al. [51] found significant improvement in the airway dimensions after maxillomandibular advancement.

This systematic review differs from the past reviews in which two-dimensional cephalography was used to assess 3-D airways. In addition, CBCT measures the transverse dimension and evaluates the volume rather than the area. However, there are also some technical issues with the $\mathrm{CBCT}$ with regard to quantifying the airway volume. Most of the included studies captured the CBCT images in an upright position with the Frankfort Horizontal (FH) plane parallel to the ground $[13,21,22]$ or the head in the natural head position $[4,12,22]$. Only the study by Li et al. [23] considered CBCT in a supine position with the FH plane perpendicular to the ground. The dimension of the upper airway is sensitive to the body position [52], and the volume at the supine position is important because obstructive sleep apnoea occurs only during sleep. Although CBCT provides a clear picture of the hard and soft tissues at a single point in time, it does not provide any information on the muscle tone or susceptibility of collapse. Hence, the use of CBCT alone is not valuable for the diagnosis of obstructive sleep apnoea [10].

Most of the studies in this review consisted of adolescent participants. It is well known that the pharyngeal airway continues its growth along with the other craniofacial structures until 18 years of age, and future growth of the airway can compensate for any change resulting from the treatment. Furthermore, a shorter duration of follow-up cannot give a clear picture of the result in the long term which is most important for the patient and clinician. In addition, assessment of the respiratory functions and sleep quality would have more clinical applicability. The inclusion of randomised trials with large samples and a longer duration of follow-up would yield a better quality of evidence.

\section{Conclusions}

There is considerable heterogeneity in the available literature with regard to the methodology of the assessment of the airway after different orthodontic therapies. Within the limitations of this study, we conclude that rapid maxillary expansion and surgical advancement for the correction of Class II patients are associated with significant improvement in the upper airway, whereas maxillary protraction, extraction therapy, orthognathic surgery for Class III, and the use of a functional appliance have no significant impact.

Author Contributions: Conceptualization, M.K.A., H.J.A., S.H.A., R.A. and S.A.R.; methodology, M.K.A. and H.J.A.; software, M.K.A. and H.J.A.; validation, M.K.A. and H.J.A.; formal analysis, M.K.A., H.J.A. and S.A.R.; investigation, M.K.A., H.J.A. and S.A.R.; resources, M.K.A., H.J.A. and S.A.R.; data curation, M.K.A. and H.J.A.; writing-original draft preparation, M.K.A., H.J.A., S.A.R., R.A. and S.H.A.; writing-review and editing, M.K.A., H.J.A., S.A.R., R.A. and S.H.A.; funding acquisition, M.K.A. All authors have read and agreed to the published version of the manuscript. 
Funding: The authors extend their appreciation to the Deanship of Scientific Research at Jouf University for funding this work through research grant no. (DSR-2021-01-0394).

Institutional Review Board Statement: Not apllicable.

Informed Consent Statement: Not apllicable.

Data Availability Statement: The data used to support the findings of this study are included in the article.

Conflicts of Interest: The authors declare no conflict of interest.

\section{Appendix A}

List of Tables

Table A1. PICO details.

\begin{tabular}{cc}
\hline Participants $(p)$ & $\begin{array}{c}\text { Studies on Human Participants of Any Gender or Malocclusion } \\
\text { Undergo Orthodontic Treatment }\end{array}$ \\
\hline $\begin{array}{c}\text { Intervention }(\mathrm{I}) \\
\text { Control (C) }\end{array}$ & $\begin{array}{c}\text { Orthodontic treatment } \\
\text { Outcome (O) }\end{array}$ \\
\hline
\end{tabular}


Table A2. Risk of bias assessment of the inlcuded studies.

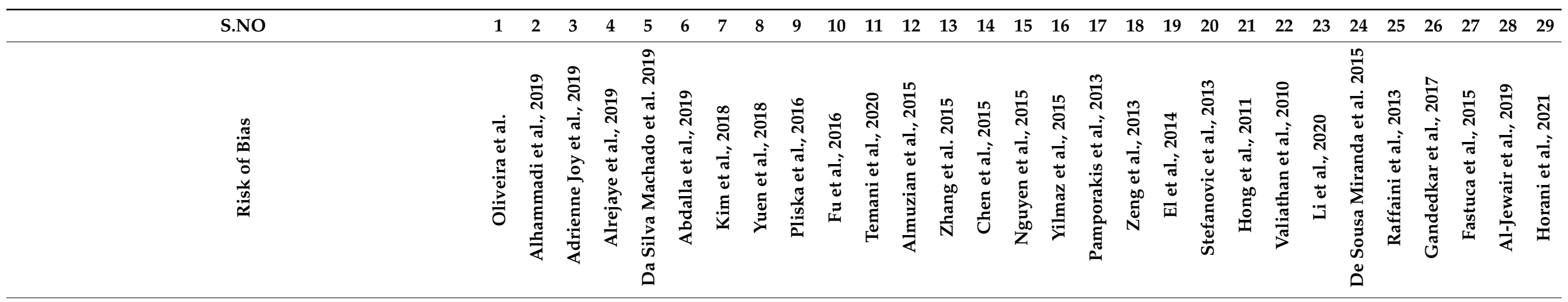

Was random sequence generation used (i.e., no potential for selection bias)?

Was allocation concealment used (i.e., no potential for selection bias)?

Was there blinding of participants and personnel (i.e., no potential for performance bias)?

Was there blinding of outcome assessment (i.e., no potential for detection bias)?

Was an objective outcome used?

Were more than $(80 \%)$ a of participants enrolled in trials included in the analysis? (i.e., no potential attrition bias)

Were data reported consistently for the outcome of

interest (i.e., no potential selective reporting)? (no potential reporting bias)

No other biases reported? (no potential of other bias) Did the trials end as scheduled (i.e., not stopped early)? Inconsistency

Point estimates did not vary widely? (i.e., no clinical meaningful inconsistency)

To what extent do confidence intervals overlap? Was the direction of effect consistent?

$\begin{array}{llllllllllllllllllllllllllllllllllllllll}\mathrm{L} & \mathrm{M} & \mathrm{L} & \mathrm{H} & \mathrm{H} & \mathrm{L} & \mathrm{M} & \mathrm{L} & \mathrm{M} & \mathrm{M} & \mathrm{M} & \mathrm{L} & \mathrm{L} & \mathrm{L} & \mathrm{M} & \mathrm{M} & \mathrm{M} & \mathrm{L} & \mathrm{H} & \mathrm{H} & \mathrm{H} & \mathrm{H} & \mathrm{L} & \mathrm{L} & \mathrm{H} & \mathrm{L} & \mathrm{H} & \mathrm{L} & \mathrm{L}\end{array}$ $\begin{array}{lllllllllllllllllllllllllllllllllllllll}\text { L } & \text { L } & \text { M } & \text { L } & \text { M } & \text { L } & \text { M } & \text { L } & \text { M } & \text { M } & \text { H } & \text { H } & \text { M } & \text { M } & \text { H } & \text { H } & \text { H } & \text { M } & \text { M } & \text { H } & \text { L } & \text { L } & \text { L } & \text { M } & \text { M } & \text { M } & \text { M } & \text { L } & \text { M }\end{array}$

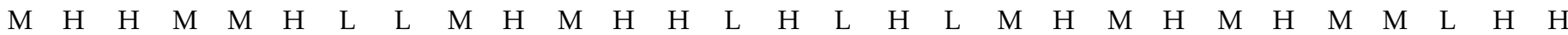
$\begin{array}{llllllllllllllllllllllllllllllllllllllll}\text { M } & \text { M } & \text { H } & \text { M } & \text { M } & \text { H } & \text { L } & \text { M } & \text { L } & \text { L } & \text { M } & \text { L } & \text { L } & \text { M } & \text { L } & \text { M } & \text { M } & \text { M } & \text { L } & \text { M } & \text { L } & \text { M } & \text { L } & \text { L } & \text { M } & \text { L } & \text { H } & \text { H } & \text { H }\end{array}$

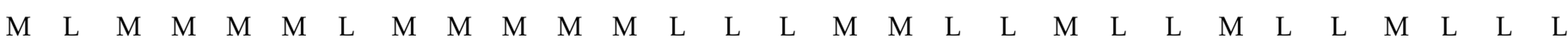
$\begin{array}{lllllllllllllllllllllllllllllllllllllllll}M & \mathrm{~L} & \mathrm{M} & \mathrm{M} & \mathrm{M} & \mathrm{H} & \mathrm{M} & \mathrm{M} & \mathrm{M} & \mathrm{M} & \mathrm{L} & \mathrm{H} & \mathrm{H} & \mathrm{H} & \mathrm{L} & \mathrm{M} & \mathrm{L} & \mathrm{M} & \mathrm{L} & \mathrm{M} & \mathrm{L} & \mathrm{M} & \mathrm{L} & \mathrm{L} & \mathrm{H} & \mathrm{L} & \mathrm{H} & \mathrm{M} & \mathrm{M}\end{array}$ $\begin{array}{llllllllllllllllllllllllllllllllllllllllll}H & \mathrm{~L} & \mathrm{H} & \mathrm{H} & \mathrm{H} & \mathrm{H} & \mathrm{L} & \mathrm{M} & \mathrm{M} & \mathrm{L} & \mathrm{M} & \mathrm{L} & \mathrm{H} & \mathrm{H} & \mathrm{M} & \mathrm{H} & \mathrm{M} & \mathrm{H} & \mathrm{M} & \mathrm{L} & \mathrm{M} & \mathrm{L} & \mathrm{L} & \mathrm{M} & \mathrm{H} & \mathrm{M} & \mathrm{M} & \mathrm{L} & \mathrm{L}\end{array}$

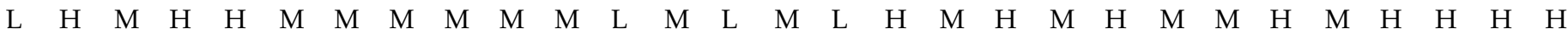
$\begin{array}{llllllllllllllllllllllllllllllll}M & H & H & L & L & M & M & M & \text { L } & \text { M } & \text { L } & \text { L } & \text { L } & \text { L } & \text { M } & \text { H } & \text { M } & \text { H } & \text { H } & \text { L } & \text { L } & \text { L } & \text { M } & \text { H } & \text { L } & \text { H } & \text { L } & \text { M } & \text { M }\end{array}$ $\begin{array}{lllllllllllllllllllllllllllllllllllllll}\text { M } & \text { L } & \text { L } & \text { M } & \text { M } & \text { M } & \text { M } & \text { M } & \text { M } & \text { M } & \text { M } & \text { M } & \text { L } & \text { M } & \text { H } & \text { H } & \text { M } & \text { H } & \text { H } & \text { M } & \text { L } & \text { M } & \text { L } & \text { H } & \text { M } & \text { H } & \text { L } & \text { L } & \text { L }\end{array}$ $\begin{array}{llllllllllllllllllllllllllllllllllllllll}\text { M } & \text { M } & \text { L } & \text { M } & \text { M } & \text { L } & \text { L } & \text { M } & \text { H } & \text { H } & \text { L } & \text { L } & \text { H } & \text { H } & \text { H } & \text { M } & \text { L } & \text { M } & \text { H } & \text { H } & \text { L } & \text { L } & \text { M } & \text { L } & \text { L } & \text { M } & \text { M } & \text { L } & \text { L }\end{array}$ \begin{tabular}{lllllllllllllllllllllllllllll}
$\mathrm{H}$ & $\mathrm{H}$ & $\mathrm{L}$ & $\mathrm{L}$ & $\mathrm{H}$ & $\mathrm{L}$ & $\mathrm{L}$ & $\mathrm{M}$ & $\mathrm{M}$ & $\mathrm{M}$ & $\mathrm{H}$ & $\mathrm{H}$ & $\mathrm{L}$ & $\mathrm{H}$ & $\mathrm{L}$ & $\mathrm{M}$ & $\mathrm{M}$ & $\mathrm{M}$ & $\mathrm{L}$ & $\mathrm{H}$ & $\mathrm{L}$ & $\mathrm{H}$ & $\mathrm{H}$ & $\mathrm{L}$ & $\mathrm{H}$ & $\mathrm{H}$ & $\mathrm{H}$ & $\mathrm{L}$ & $\mathrm{M}$ \\
\hline
\end{tabular} 
Table A2. Cont.

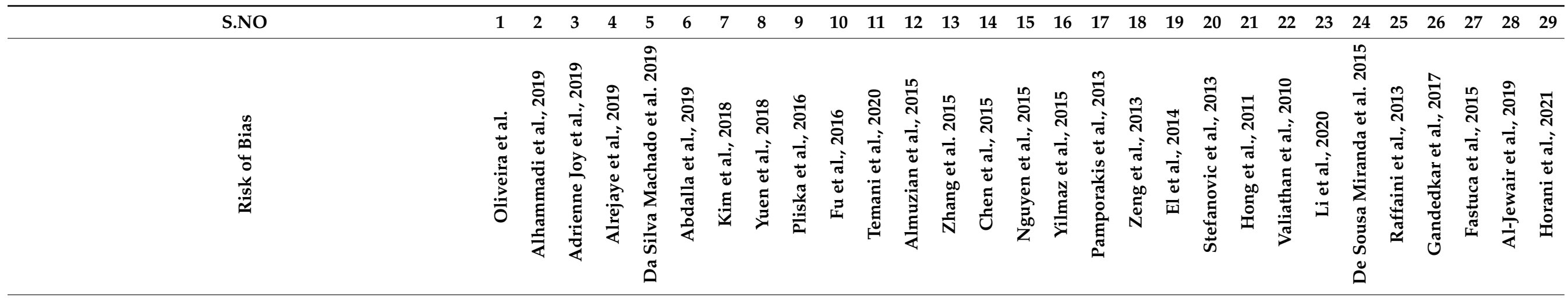

What was the magnitude of statistical heterogeneity (as measured by $\left.I^{2}\right)$ ?

Was the test for heterogeneity statistically significant

$$
(p<0.1) \text { ? }
$$

$$
\text { Indirectness }
$$

Were the populations in included studies applicable to

the target population?

Were the interventions in

$$
\text { included studies }
$$

applicable to target intervention?

$$
\text { Was the }
$$

included outcome not a surrogate outcome?

Was the outcome timeframe sufficient?

Were the conclusions based on direct comparisons?

$$
\text { Imprecision }
$$

Was the confidence interval for the pooled estimate not

$$
\text { consistent with }
$$

benefit and harm?

What was the

magnitude of the

median sample size? $\begin{array}{lllllllllllllllllllllllllllllllllllllllll}\text { H } & \text { M } & \text { L } & \text { M } & \text { H } & \text { L } & \text { L } & \text { L } & \text { L } & \text { M } & \text { M } & \text { L } & \text { M } & \text { L } & \text { M } & \text { L } & \text { M } & \text { L } & \text { L } & \text { M } & \text { L } & \text { M } & \text { L } & \text { H } & \text { L } & \text { H } & \text { L } & \text { H } & \text { L }\end{array}$

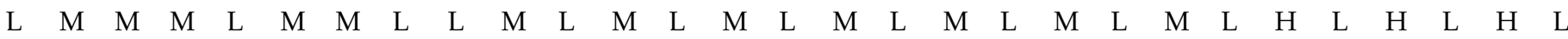

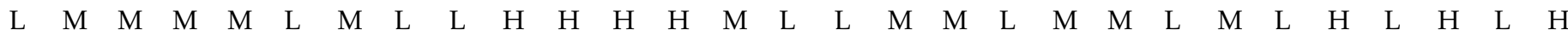

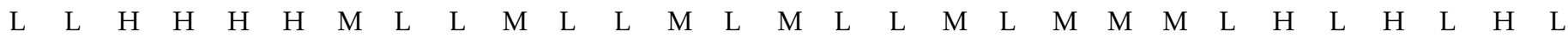

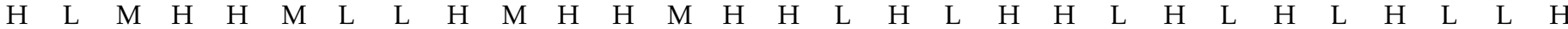
$\begin{array}{lllllllllllllllllllllllllllllllllllll}\text { M } & \text { M } & \text { M } & \text { H } & \text { L } & \text { L } & \text { L } & \text { H } & \text { L } & \text { M } & \text { L } & \text { L } & \text { M } & \text { L } & \text { L } & \text { M } & \text { M } & \text { L } & \text { L } & \text { M } & \text { L } & \text { M } & \text { L } & \text { L } & \text { L } & \text { M } & \text { L } & \text { M } & \text { L }\end{array}$

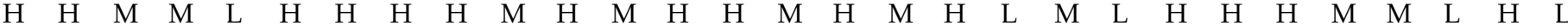

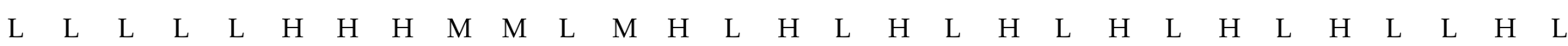
$\begin{array}{lllllllllllllllllllllllllllllllllllllllllll}\text { L } & \text { L } & \text { L } & \text { L } & \text { L } & \text { H } & \text { M } & \text { H } & \text { M } & \text { L } & \text { M } & \text { M } & \text { L } & \text { M } & \text { L } & \text { M } & \text { L } & \text { M } & \text { L } & \text { H } & \text { L } & \text { H } & \text { L } & \text { H } & \text { L } & \text { H } & \text { H } & \text { L } & \text { L }\end{array}$ 
Table A2. Cont.

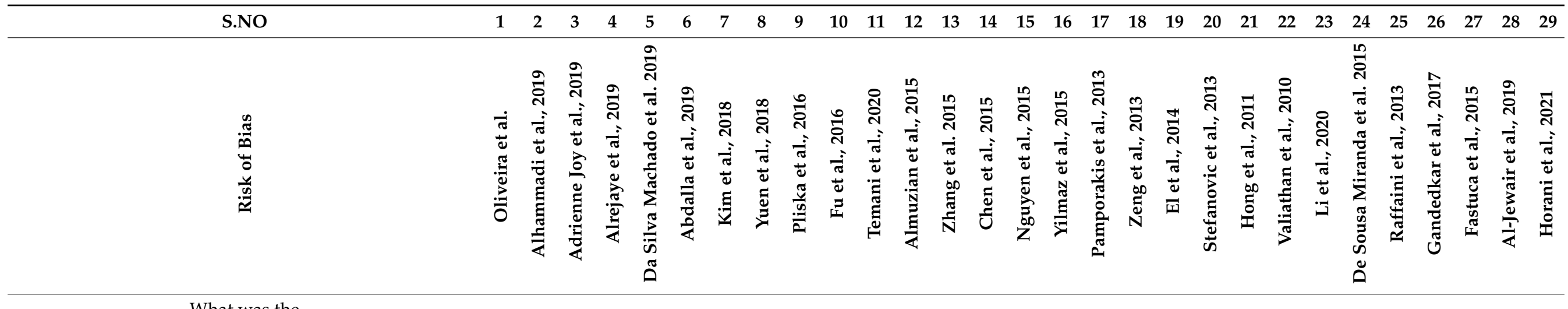

magnitude of the number of included studies?

Was the outcome a common event? (e.g.,

occurs more than $1 / 100$ ) a

Was there no

evidence of serious harm

associated with

treatment?

Publication bias

Did the

authors conduct a comprehensive search?

Did the

authors search for grey

literature?

Authors did not

apply restrictions to study

selection on the basis of language?

$$
\text { There was no }
$$

industry influence on studies included in the review? There was no

evidence of funnel plot asymmetry?

$\begin{array}{lllllllllllllllllllllllllllllllllllll}\mathrm{L} & \mathrm{M} & \mathrm{M} & \mathrm{M} & \mathrm{M} & \mathrm{M} & \mathrm{L} & \mathrm{L} & \mathrm{L} & \mathrm{M} & \mathrm{L} & \mathrm{M} & \mathrm{L} & \mathrm{M} & \mathrm{L} & \mathrm{M} & \mathrm{L} & \mathrm{M} & \mathrm{L} & \mathrm{M} & \mathrm{L} & \mathrm{M} & \mathrm{L} & \mathrm{H} & \mathrm{L} & \mathrm{H} & \mathrm{H} & \mathrm{L} & \mathrm{H}\end{array}$ $\begin{array}{lllllllllllllllllllllllllllllllllll}\text { M } & \text { L } & \text { M } & \text { H } & \text { M } & \text { L } & \text { M } & \text { L } & \text { H } & \text { H } & \text { H } & \text { H } & \text { L } & \text { H } & \text { L } & \text { L } & \text { L } & \text { M } & \text { L } & \text { M } & \text { L } & \text { M } & \text { L } & \text { M } & \text { L } & \text { L } & \text { M } & \text { M } & \text { M }\end{array}$

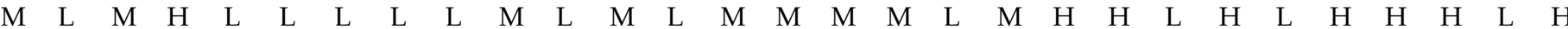
$\begin{array}{llllllllllllllllllllllllllllllllllllllll}\mathrm{L} & \mathrm{M} & \mathrm{H} & \mathrm{M} & \mathrm{M} & \mathrm{L} & \mathrm{M} & \mathrm{L} & \mathrm{M} & \mathrm{L} & \mathrm{M} & \mathrm{L} & \mathrm{M} & \mathrm{L} & \mathrm{M} & \mathrm{L} & \mathrm{M} & \mathrm{L} & \mathrm{L} & \mathrm{M} & \mathrm{L} & \mathrm{M} & \mathrm{L} & \mathrm{M} & \mathrm{L} & \mathrm{M} & \mathrm{L} & \mathrm{M} & \mathrm{M}\end{array}$

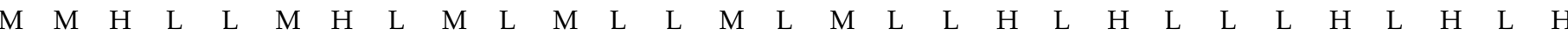

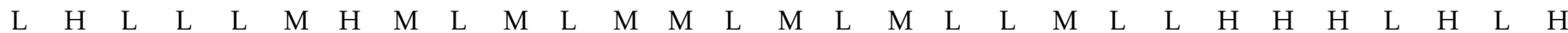

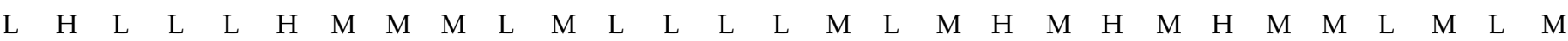
$\begin{array}{llllllllllllllllllllllllllllll}\mathrm{L} & \mathrm{L} & \mathrm{M} & \mathrm{M} & \mathrm{M} & \mathrm{H} & \mathrm{M} & \mathrm{M} & \mathrm{M} & \mathrm{L} & \mathrm{M} & \mathrm{M} & \mathrm{L} & \mathrm{M} & \mathrm{M} & \mathrm{L} & \mathrm{M} & \mathrm{M} & \mathrm{L} & \mathrm{M} & \mathrm{L} & \mathrm{M} & \mathrm{L} & \mathrm{M} & \mathrm{L} & \mathrm{M} & \mathrm{L} & \mathrm{M} & \mathrm{M}\end{array}$ There was no discrepancy in findings between published

$$
\text { and }
$$

upublished trials?

Overall score

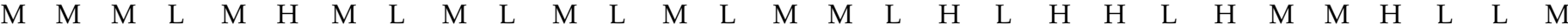

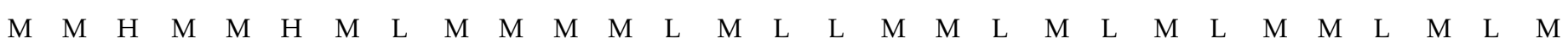


Table A3. Study characteristics.

\begin{tabular}{|c|c|c|c|c|c|c|c|c|c|c|c|c|c|c|c|}
\hline S.No & $\begin{array}{c}\text { Author \& } \\
\text { Year }\end{array}$ & Country & $\begin{array}{l}\text { Study } \\
\text { Design }\end{array}$ & $\begin{array}{l}\text { Sample } \\
\text { Size }\end{array}$ & Gender & $\begin{array}{l}\text { Age (Years) } \\
\text { Range/Mean/ } \\
\text { Median }\end{array}$ & Orthodontic & $\begin{array}{l}\text { Type of } \\
\text { Malocclu- } \\
\text { sion }\end{array}$ & $\begin{array}{l}\text { Method Used } \\
\text { to Assess the } \\
\text { Airway }\end{array}$ & $\begin{array}{c}\text { Specific } \\
\text { Airway } \\
\text { Space That } \\
\text { Was Assessed }\end{array}$ & Variables & $\begin{array}{c}\text { Actual } \\
\text { Baseline }\end{array}$ & $\begin{array}{l}\text { Follow up } \\
\text { Duration }\end{array}$ & $p$-Values & Outcome \\
\hline 1 & $\begin{array}{l}\text { Oliveira } \\
\text { et al. [39] }\end{array}$ & USA & Retrospective & 42 & $\begin{array}{c}25 / \mathrm{M} \& \\
17 / \mathrm{F}\end{array}$ & $\begin{array}{l}\text { Mean-13.8 } \\
\quad \pm 1.2\end{array}$ & $\begin{array}{c}\text { Functional } \\
\text { appliance } \\
\text { (HERBST) }\end{array}$ & $\begin{array}{l}\text { Class II } \\
\text { malocclu- } \\
\text { sion }\end{array}$ & СВСТ & $\begin{array}{l}\text { The upper } \\
\text { airway was } \\
\text { divided into } 3 \\
\text { regions: nasal } \\
\text { cavity, } \\
\text { nasopharynx, } \\
\text { and } \\
\text { oropharynx }\end{array}$ & $\begin{array}{c}\text { Functional } \\
\text { appliance: } \\
\text { Experiment: } \\
\text { Mean: } 28.5, \\
\text { SD: } 10.8, \\
\text { Control: } \\
\text { Mean: } 20.6 \text {, } \\
\text { SD: } 9.4\end{array}$ & $\begin{array}{l}\text { Class II } \\
\text { malocclu- } \\
\text { sion with } \\
\text { an ANB } \\
\text { angle }>4^{\circ}\end{array}$ & NR & $\begin{array}{c}\text { Nasal cavity- } \\
\text { HAG-0.144 } \\
\text { and } \\
\text { CG-0.046; } \\
\text { Nasopharyn- } \\
\text { HAG-0.071 } \\
\text { and } \\
\text { CG-0.211; } \\
\text { Oropharynx- } \\
\text { HAG-0.003 } \\
\text { and } \\
\text { CG-0.666 }\end{array}$ & $\begin{array}{l}\text { Increased the } \\
\text { volume of the } \\
\text { oropharynx, } \\
\text { but no } \\
\text { volumetric } \\
\text { modifications } \\
\text { in the nasal } \\
\text { cavity and } \\
\text { nasopharynx. }\end{array}$ \\
\hline 2 & $\begin{array}{l}\text { Alhammadi } \\
\text { et al. [41] }\end{array}$ & Egypt & $\begin{array}{l}\text { Controlled } \\
\text { clinical } \\
\text { study }\end{array}$ & 62 & $62 / F$ & $\begin{array}{l}\text { Mean-11.27 } \\
\quad \pm 1.19\end{array}$ & $\begin{array}{c}\text { Functional } \\
\text { appliance } \\
\text { (Twinblock } \\
\text { \& Forsus } \\
\text { Fatigue } \\
\text { Resistance } \\
\text { Device) }\end{array}$ & $\begin{array}{l}\text { Class II } \\
\text { malocclu- } \\
\text { sion }\end{array}$ & $\begin{array}{l}\text { Pre- and post- } \\
\text { treatment/ } \\
\text { observational } \\
\text { cone beam } \\
\text { computed } \\
\text { tomography }\end{array}$ & $\begin{array}{l}\text { Pharyngeal } \\
\text { airway }\end{array}$ & $\begin{array}{c}\text { Functional } \\
\text { appliance: } \\
\text { Experiment: } \\
\text { Mean:16.8, } \\
\text { SD: } 3.26, \\
\text { Control: } \\
\text { Mean: } 20.1 \text {, } \\
\text { SD: } 2.7\end{array}$ & NR & $\begin{array}{l}\text { Every } 4 \\
\text { weeks }\end{array}$ & $\begin{array}{c}\text { TWB } \\
(p<0.001)\end{array}$ & $\begin{array}{l}\text { Twin block } \\
\text { functional } \\
\text { appliance } \\
\text { induced } \\
\text { significant } \\
\text { pharyngeal } \\
\text { airway } \\
\text { changes than } \\
\text { Forsus }\end{array}$ \\
\hline 3 & $\begin{array}{c}\text { Adrienne } \\
\text { Joy et al. } \\
\text { [53] }\end{array}$ & USA & $\begin{array}{l}\text { Retrospective } \\
\text { study }\end{array}$ & 83 & $\begin{array}{c}42 / \mathrm{M} \& \\
41 / \mathrm{F}\end{array}$ & $\begin{array}{c}\text { Mean-26.1 } \\
\quad \pm 7.1\end{array}$ & Extraction & NR & СВСТ & $\begin{array}{l}\text { Various } \\
\text { airway } \\
\text { measures in } \\
\text { the } \\
\text { nasopharynx, } \\
\text { retropalatal, } \\
\text { or } \\
\text { retroglossal } \\
\text { regions. }\end{array}$ & $\begin{array}{l}\text { Extraction: } \\
\text { Mean-20.8, } \\
\text { SD-10.3, Non- } \\
\text { extraction: } \\
\text { Mean-18.5, } \\
\text { SD-8.0 }\end{array}$ & $\begin{array}{l}\text { baseline } \\
\text { MCA was } \\
\text { less than } \\
100 \mathrm{~mm}^{2} \text { or } \\
\text { greater } \\
\text { than } 200 \\
\mathrm{~mm}^{2} .\end{array}$ & NR & $p<0.001$ & No effect \\
\hline 4 & $\begin{array}{l}\text { Alrejaye } \\
\text { et al. [3] }\end{array}$ & USA & $\begin{array}{l}\text { Retrospective } \\
\text { study }\end{array}$ & 26 & $\begin{array}{c}14 / \mathrm{M} \& \\
12 / \mathrm{F}\end{array}$ & $\begin{array}{c}\text { Mean-8.4 } \pm \\
1.7\end{array}$ & $\begin{array}{l}\text { Maxillary } \\
\text { expansion } \\
\text { with } \\
\text { protraction }\end{array}$ & NR & СВСТ & $\begin{array}{c}\text { Oropharyngeal } \\
\text { airway }\end{array}$ & $\begin{array}{l}\text { Experimental: } \\
\text { Mean-10.3, } \\
\text { SD-, Control: } \\
\text { Mean-8.7, SD- } \\
\text { Surgery Class }\end{array}$ & NR & NR & $\begin{array}{l}p \text {-value: } \\
<0.0001\end{array}$ & No effect \\
\hline 5 & $\begin{array}{l}\text { Da Silva } \\
\text { Machado } \\
\text { et al. [48] }\end{array}$ & Brazil & $\begin{array}{l}\text { Quasi- } \\
\text { experimental } \\
\text { study }\end{array}$ & 13 & NR & NR & $\begin{array}{l}\text { Class III } \\
\text { surgery }\end{array}$ & $\begin{array}{l}\text { Class III } \\
\text { malocclu- } \\
\text { sion }\end{array}$ & $\begin{array}{l}\text { multislice } \\
\text { computed } \\
\text { tomography }\end{array}$ & $\begin{array}{c}\text { Pharyngeal } \\
\text { airway }\end{array}$ & $\begin{array}{c}\text { III } \\
\text { Experimental: } \\
\text { Mean- 21.2, } \\
\text { SD-6.4 } \\
\text { Control: } \\
\text { Mean- } 24.0 \\
\text { SD- } 8.3\end{array}$ & NR & NR & $p<0.05$ & $\begin{array}{c}\text { Increase } \\
\text { airway space }\end{array}$ \\
\hline
\end{tabular}


Table A3. Cont.

\begin{tabular}{|c|c|c|c|c|c|c|c|c|c|c|c|c|c|c|c|}
\hline S.No & $\begin{array}{c}\text { Author \& } \\
\text { Year }\end{array}$ & Country & $\begin{array}{c}\text { Study } \\
\text { Design }\end{array}$ & $\begin{array}{c}\text { Sample } \\
\text { Size }\end{array}$ & Gender & $\begin{array}{l}\text { Age (Years) } \\
\text { Range/Mean/ } \\
\text { Median }\end{array}$ & Orthodontic & $\begin{array}{l}\text { Type of } \\
\text { Malocclu- } \\
\text { sion }\end{array}$ & $\begin{array}{l}\text { Method Used } \\
\text { to Assess the } \\
\text { Airway }\end{array}$ & $\begin{array}{c}\text { Specific } \\
\text { Airway } \\
\text { Space That } \\
\text { Was Assessed }\end{array}$ & Variables & $\begin{array}{c}\text { Actual } \\
\text { Baseline }\end{array}$ & $\begin{array}{l}\text { Follow up } \\
\text { Duration }\end{array}$ & $p$-Values & Outcome \\
\hline 6 & $\begin{array}{l}\text { Abdalla } \\
\text { et al. [21] }\end{array}$ & Australia & $\begin{array}{l}\text { Retrospective } \\
\text { study }\end{array}$ & 26 & $\begin{array}{l}14 / \mathrm{F} \& \\
12 / \mathrm{M}\end{array}$ & $\begin{array}{c}\text { Mean-12 } \\
\text { years, } 4 \\
\text { months } \pm 2 \\
\text { years, } 4 \\
\text { months }\end{array}$ & $\begin{array}{c}\text { Rapid } \\
\text { maxillary } \\
\text { expansion }\end{array}$ & $\begin{array}{l}\text { Minor mal- } \\
\text { occlusions }\end{array}$ & СВСТ & $\begin{array}{c}\text { Pharyngeal } \\
\text { airway }\end{array}$ & $\begin{array}{c}\text { Experimental: } \\
\text { Mean-17.5 } \\
\text { SD-, Control: } \\
\text { Mean-15.8, } \\
\text { SD- }\end{array}$ & NR & NR & $p<0.001$ & No effect \\
\hline 7 & $\begin{array}{c}\text { Kim et al. } \\
\text { [15] }\end{array}$ & $\begin{array}{l}\text { South } \\
\text { Korea }\end{array}$ & $\begin{array}{l}\text { Retrospective } \\
\text { study }\end{array}$ & 14 & $\begin{array}{c}10 / \mathrm{F} \& \\
4 / \mathrm{M}\end{array}$ & $\begin{array}{c}\text { Mean-22.7 } \\
\pm 3.3\end{array}$ & $\begin{array}{c}\text { Rapid } \\
\text { maxillary } \\
\text { expansion }\end{array}$ & NR & СВСТ & Nasal airway & $\begin{array}{c}\text { Maxillary } \\
\text { Expansion } \\
\text { Experimental: } \\
\text { Mean-1.6, } \\
\text { SD-0.9 } \\
\text { Control: } \\
\text { Mean- 25.1, } \\
\text { SD-3.4 }\end{array}$ & NR & 12-year & $p<0.05$ & Increase \\
\hline 8 & $\begin{array}{l}\text { Yuen et al. } \\
\text { [54] }\end{array}$ & USA & $\begin{array}{l}\text { Retrospective } \\
\text { study }\end{array}$ & 137 & $\begin{array}{c}126 / \mathrm{F} \& \\
11 / \mathrm{M}\end{array}$ & NR & $\begin{array}{l}\text { Class II } \\
\text { surgery }\end{array}$ & NR & СВСТ & $\begin{array}{c}\text { Pharyngeal } \\
\text { airway }\end{array}$ & $\begin{array}{l}\text { Pre-surgical: } \\
\text { Mean-9.0, } \\
\text { SD-4.1, } \\
\text { Post-surgical: } \\
\text { Mean-12.0, } \\
\text { SD-5.3 }\end{array}$ & NR & $\begin{array}{l}\text { 1-year after } \\
\text { surgery }\end{array}$ & $\begin{array}{l}p \text {-value: } \\
<0.0001\end{array}$ & Increase \\
\hline 9 & $\begin{array}{c}\text { Pliska } \\
\text { et al. [11] }\end{array}$ & Minneapolis & $\begin{array}{l}\text { Retrospective } \\
\text { study }\end{array}$ & 74 & $\begin{array}{c}25 / \mathrm{M} \& \\
49 / \mathrm{F}\end{array}$ & $\begin{array}{c}\text { Mean-31.9 } \\
\pm 12.0\end{array}$ & Extraction & NR & СВСТ & $\begin{array}{l}\text { Orthodontic } \\
\text { upper airway }\end{array}$ & $\begin{array}{l}\text { Extraction } \\
\text { non } \\
\text { extractionEx- } \\
\text { perimental: } \\
\text { Mean-20.0564, } \\
\text { SD-6.8488 } \\
\text { Control: } \\
\text { Mean-25.9513, } \\
\text { SD-8.1603 } \\
\text { Expansion }\end{array}$ & $\begin{array}{c}\text { Class II } \\
\text { (ANB angle } \\
>4^{\circ}\end{array}$ & NR & NR & No change \\
\hline 10 & $\begin{array}{l}\text { Fu et al. } \\
\text { [26] }\end{array}$ & China & $\begin{array}{l}\text { Longitudinal } \\
\text { study }\end{array}$ & 18 & $\begin{array}{c}\text { 13/M \& } \\
5 / \mathrm{F}\end{array}$ & $\begin{array}{c}\text { Mean-9.6 } \pm \\
1.7\end{array}$ & $\begin{array}{c}\text { Rapid } \\
\text { maxillary } \\
\text { expansion } \\
\text { with } \\
\text { protraction }\end{array}$ & $\begin{array}{l}\text { Class III } \\
\text { malocclu- } \\
\text { sion }\end{array}$ & СВСТ & $\begin{array}{c}\text { Pharyngeal } \\
\text { airway }\end{array}$ & $\begin{array}{c}\text { with } \\
\text { Protraction } \\
\text { Experimental: } \\
\text { Mean-9.2481, } \\
\text { SD-3.237 } \\
\text { Control: } \\
\text { Mean-12.9176, } \\
\text { SD-5.193 }\end{array}$ & NR & NR & $p<0.001$ & Increase \\
\hline 11 & $\begin{array}{l}\text { Temani } \\
\text { et al. [40] }\end{array}$ & India & $\begin{array}{l}\text { Prospective } \\
\text { study }\end{array}$ & 30 & NR & NR & $\begin{array}{l}\text { Functional } \\
\text { appliance }\end{array}$ & $\begin{array}{l}\text { Class II } \\
\text { malocclu- } \\
\text { sion }\end{array}$ & СВСТ & $\begin{array}{c}\text { Pharyngeal } \\
\text { airway }\end{array}$ & $\begin{array}{c}\text { Functional } \\
\text { appliance: } \\
\text { Experiment: } \\
\text { Mean:20.0, } \\
\text { SD: } 4.4, \\
\text { Control: } \\
\text { Mean: } 15.9 \\
\text { SD: } 4.6\end{array}$ & NR & $\begin{array}{l}\text { Longer } \\
\text { period of } \\
\text { follow-up }\end{array}$ & $p<0.001$ & Increase \\
\hline
\end{tabular}


Table A3. Cont.

\begin{tabular}{|c|c|c|c|c|c|c|c|c|c|c|c|c|c|c|c|}
\hline S.No & $\begin{array}{c}\text { Author \& } \\
\text { Year }\end{array}$ & Country & $\begin{array}{l}\text { Study } \\
\text { Design }\end{array}$ & $\begin{array}{l}\text { Sample } \\
\text { Size }\end{array}$ & Gender & $\begin{array}{l}\text { Age (Years) } \\
\text { Range/Mean/ } \\
\text { Median }\end{array}$ & Orthodontic & $\begin{array}{l}\text { Type of } \\
\text { Malocclu- } \\
\text { sion }\end{array}$ & $\begin{array}{l}\text { Method Used } \\
\text { to Assess the } \\
\text { Airway }\end{array}$ & $\begin{array}{c}\text { Specific } \\
\text { Airway } \\
\text { Space That } \\
\text { Was Assessed }\end{array}$ & Variables & $\begin{array}{c}\text { Actual } \\
\text { Baseline }\end{array}$ & $\begin{array}{l}\text { Follow up } \\
\text { Duration }\end{array}$ & $p$-Values & Outcome \\
\hline 12 & $\begin{array}{l}\text { Almuzian } \\
\text { et al. [13] }\end{array}$ & Australia & $\begin{array}{l}\text { Prospective } \\
\text { study }\end{array}$ & 17 & 8/M \& 9/F & $\begin{array}{c}\text { Mean-12.6 } \\
\quad \pm 1.8\end{array}$ & $\begin{array}{c}\text { Rapid } \\
\text { maxillary } \\
\text { expansion }\end{array}$ & NR & СВСТ & $\begin{array}{l}\text { Nasopharyngeal } \\
\text { airway }\end{array}$ & $\begin{array}{l}\text { Experimental: } \\
\text { Mean-17.45, } \\
\text { SD-1.47, } \\
\text { Control: } \\
\text { Mean-16.4, } \\
\text { SD-0.8 }\end{array}$ & NR & $\begin{array}{l}\text { Longer } \\
\text { term } \\
\text { follow-up }\end{array}$ & $p<0.05$ & Increase \\
\hline 13 & $\begin{array}{l}\text { Zhang } \\
\text { et al. [12] }\end{array}$ & China & $\begin{array}{l}\text { Retrospective } \\
\text { study }\end{array}$ & 18 & $\begin{array}{l}5 / \mathrm{M} \& \\
13 / \mathrm{F}\end{array}$ & $\begin{array}{l}\text { Mean-24.1 } \\
\quad \pm 3.8\end{array}$ & Extraction & $\begin{array}{l}\text { Class II } \\
\text { malocclu- } \\
\text { sion }\end{array}$ & СВСТ & $\begin{array}{l}\text { The upper } \\
\text { airway was } \\
\text { divided into } \\
\text { nasopharynx, } \\
\text { velopharynx, } \\
\text { and } \\
\text { hypopharynx }\end{array}$ & $\begin{array}{l}\text { Extraction: } \\
\text { Mean-49.8, } \\
\text { SD-, Non- } \\
\text { extraction: } \\
\text { Mean-241, } \\
\text { SD- }\end{array}$ & NR & $\begin{array}{l}\text { Greater } \\
\text { length of } \\
\text { follow-up }\end{array}$ & $p<0.01$ & Decrease \\
\hline 14 & $\begin{array}{l}\text { Chen et al. } \\
\text { [55] }\end{array}$ & China & $\begin{array}{l}\text { Retrospective } \\
\text { study }\end{array}$ & 60 & $\begin{array}{l}28 / \mathrm{F} \& \\
32 / \mathrm{M}\end{array}$ & $\begin{array}{c}\text { Mean- } \\
7 \pm 1.21\end{array}$ & $\begin{array}{c}\text { Rapid } \\
\text { maxillary } \\
\text { expansion } \\
\text { with } \\
\text { protraction }\end{array}$ & $\begin{array}{l}\text { Class III } \\
\text { malocclu- } \\
\text { sion }\end{array}$ & СВСТ & $\begin{array}{l}\text { Upper airway } \\
\text { of } \\
\text { nasopharynx, } \\
\text { velopharynx }\end{array}$ & $\begin{array}{l}\text { Experimental: } \\
\text { Mean-11.7 } \\
\text { SD-4.4, } \\
\text { Control: } \\
\text { Mean-21.3, } \\
\text { SD-12.5 }\end{array}$ & NR & NR & $p<0.05$ & Increase \\
\hline 15 & $\begin{array}{l}\text { Nguyen } \\
\text { et al. [56] }\end{array}$ & $\begin{array}{l}\text { North } \\
\text { Carolina }\end{array}$ & $\begin{array}{l}\text { Prospective } \\
\text { study }\end{array}$ & 28 & $\begin{array}{l}14 / \mathrm{F} \& \\
14 / \mathrm{M}\end{array}$ & NR & $\begin{array}{c}\text { Rapid } \\
\text { maxillary } \\
\text { expansion } \\
\text { with } \\
\text { protraction }\end{array}$ & $\begin{array}{l}\text { Class III } \\
\text { malocclu- } \\
\text { sion }\end{array}$ & СВСТ & $\begin{array}{l}\text { Nasopharyngeal, } \\
\text { oropharynx } \\
\text { airway }\end{array}$ & $\begin{array}{c}\text { Expansion } \\
\text { with } \\
\text { Protraction } \\
\text { Experimental: } \\
\text { Mean-14.14, } \\
\text { SD-3.76173 } \\
\text { Control: } \\
\text { Mean-14.56, } \\
\text { SD-5.74 }\end{array}$ & NR & NR & $p<0.05$ & No effect \\
\hline 16 & $\begin{array}{l}\text { Yilmaz } \\
\text { et al. [57] }\end{array}$ & Turkey & $\begin{array}{l}\text { Prospective } \\
\text { study }\end{array}$ & 20 & $\begin{array}{l}10 / \mathrm{F} \& \\
10 / \mathrm{M}\end{array}$ & Mean-9 & $\begin{array}{c}\text { Rapid } \\
\text { maxillary } \\
\text { expansion }\end{array}$ & $\begin{array}{l}\text { Class III } \\
\text { malocclu- } \\
\text { sion }\end{array}$ & СВСТ & $\begin{array}{l}\text { The airway } \\
\text { was divided } \\
\text { into three } \\
\text { parts; } \\
\text { pharyngeal, } \\
\text { nasal, and } \\
\text { anterior nasal } \\
\text { compart- } \\
\text { ments }\end{array}$ & $\begin{array}{c}\text { Maxillary } \\
\text { Expansion } \\
\text { Experimental: } \\
\text { Mean-3.1967, } \\
\text { SD-0.967 } \\
\text { Control: } \\
\text { Mean-3.51, } \\
\text { SD-0.9 }\end{array}$ & NR & 9 weeks & $p<0.05$ & Increase \\
\hline 17 & $\begin{array}{l}\text { Pamporakis } \\
\text { et al. [58] }\end{array}$ & Turkey & $\begin{array}{l}\text { Retrospective } \\
\text { study }\end{array}$ & 22 & $\begin{array}{l}14 / \mathrm{F} \& \\
8 / \mathrm{M}\end{array}$ & Mean-10 & Protraction & $\begin{array}{l}\text { Class III } \\
\text { malocclu- } \\
\text { sion }\end{array}$ & СВСТ & $\begin{array}{c}\text { Pharyngeal } \\
\text { airway }\end{array}$ & $\begin{array}{c}\text { Expansion } \\
\text { with } \\
\text { Protraction } \\
\text { Experimental: } \\
\text { Mean-9.1, } \\
\text { SD-2.0 } \\
\text { Control: } \\
\text { Mean-9.5, } \\
\text { SD-2.4 }\end{array}$ & NR & NR & $p<0.05$ & Increase \\
\hline
\end{tabular}


Table A3. Cont.

\begin{tabular}{|c|c|c|c|c|c|c|c|c|c|c|c|c|c|c|c|}
\hline S.No & $\begin{array}{c}\text { Author \& } \\
\text { Year }\end{array}$ & Country & $\begin{array}{c}\text { Study } \\
\text { Design }\end{array}$ & $\begin{array}{l}\text { Sample } \\
\text { Size }\end{array}$ & Gender & $\begin{array}{l}\text { Age (Years) } \\
\text { Range/Mean/ } \\
\text { Median }\end{array}$ & Orthodontic & $\begin{array}{l}\text { Type of } \\
\text { Malocclu- } \\
\text { sion }\end{array}$ & $\begin{array}{l}\text { Method Used } \\
\text { to Assess the } \\
\text { Airway }\end{array}$ & $\begin{array}{c}\text { Specific } \\
\text { Airway } \\
\text { Space That } \\
\text { Was Assessed }\end{array}$ & Variables & $\begin{array}{c}\text { Actual } \\
\text { Baseline }\end{array}$ & $\begin{array}{l}\text { Follow up } \\
\text { Duration }\end{array}$ & $p$-Values & Outcome \\
\hline 18 & $\begin{array}{l}\text { Zeng et al. } \\
\text { [22] }\end{array}$ & China & $\begin{array}{l}\text { Prospective } \\
\text { study }\end{array}$ & 16 & $\begin{array}{l}6 / \mathrm{F} \& \\
10 / \mathrm{M}\end{array}$ & $\begin{array}{l}\text { Mean-12.73 } \\
\quad \pm 1.73\end{array}$ & $\begin{array}{c}\text { Rapid } \\
\text { maxillary } \\
\text { expansion }\end{array}$ & NR & СВСТ & $\begin{array}{l}\text { Nasopharyngeal } \\
\text { airway }\end{array}$ & $\begin{array}{l}\text { Experimental: } \\
\text { Mean-12, } \\
\text { SD-4 Control: } \\
\text { Mean-13.5, } \\
\text { SD-4.8 }\end{array}$ & NR & 5 years & $p<0.0033$ & Limited effect \\
\hline 19 & $\begin{array}{l}\text { El et al. } \\
\text { [4] }\end{array}$ & USA & $\begin{array}{l}\text { Retrospective } \\
\text { study }\end{array}$ & 35 & $\begin{array}{c}15 / \mathrm{M} \& \\
20 / \mathrm{F}\end{array}$ & $\begin{array}{l}\text { Mean-14.02 } \\
\quad \pm 1.46\end{array}$ & $\begin{array}{c}\text { Rapid } \\
\text { maxillary } \\
\text { expansion }\end{array}$ & $\begin{array}{l}\text { Class I mal- } \\
\text { occlusion }\end{array}$ & СВСТ & $\begin{array}{l}\text { Oropharyngeal } \\
\text { airway }\end{array}$ & $\begin{array}{c}\text { Experimental: } \\
\text { Mean-33.2, } \\
\text { SD-9.7 } \\
\text { Control: } \\
\text { Mean-27.0, } \\
\text { SD-9.3 }\end{array}$ & NR & NR & $p<0.001$ & No change \\
\hline 20 & $\begin{array}{l}\text { Stefanovic } \\
\text { et al. [29] }\end{array}$ & USA & $\begin{array}{l}\text { Retrospective } \\
\text { study }\end{array}$ & 31 & $\begin{array}{c}15 / \mathrm{M} \& \\
16 / \mathrm{F}\end{array}$ & $\begin{array}{l}\text { Mean-12.97 } \\
\quad \pm 1.15\end{array}$ & Extraction & NR & СВСТ & $\begin{array}{c}\text { Pharyngeal } \\
\text { airway }\end{array}$ & $\begin{array}{c}\text { Extraction: } \\
\text { Mean-11.2, } \\
\text { SD-5.7, Non- } \\
\text { extraction: } \\
\text { Mean-12.6, } \\
\text { SD-6.7 }\end{array}$ & NR & NR & $p \leq 0.05$ & No change \\
\hline 21 & $\begin{array}{l}\text { Hong et al. } \\
\text { [59] }\end{array}$ & Korea & $\begin{array}{l}\text { Retrospective } \\
\text { study }\end{array}$ & 60 & $\begin{array}{c}30 / \mathrm{M} \& \\
30 / \mathrm{F}\end{array}$ & $\begin{array}{l}\text { Mean- } 26.0 \\
\quad \pm 4.5\end{array}$ & $\begin{array}{l}\text { Class III } \\
\text { surgery }\end{array}$ & $\begin{array}{l}\text { Class III } \\
\text { malocclu- } \\
\text { sion }\end{array}$ & СВСТ & $\begin{array}{c}\text { Pharyngeal } \\
\text { airway }\end{array}$ & $\begin{array}{c}\text { Surgery Class } \\
\text { III } \\
\text { Experimental: } \\
\text { Mean- } \\
33.36815, \\
\text { SD-7.3556 } \\
\text { Control: } \\
\text { Mean-34.0623, } \\
\text { SD-12.51731 }\end{array}$ & NR & NR & $p \leq 0.05$ & Increase \\
\hline 22 & $\begin{array}{l}\text { Valiathan } \\
\text { et al. [30] }\end{array}$ & USA & $\begin{array}{l}\text { Retrospective } \\
\text { study }\end{array}$ & 20 & $\begin{array}{c}10 / \mathrm{M} \& \\
10 / \mathrm{F}\end{array}$ & $\begin{array}{l}\text { Mean-13.8 } \\
\quad \pm 1.3\end{array}$ & Extraction & $\begin{array}{l}\text { Class I mal- } \\
\text { occlusion }\end{array}$ & СВСТ & $\begin{array}{c}\text { Oropharyngeal } \\
\text { airway }\end{array}$ & $\begin{array}{l}\text { Extraction } \\
\text { non } \\
\text { extraction } \\
\text { Experimental: } \\
\text { Mean-12.7, } \\
\text { SD-4.5 } \\
\text { Control: } \\
\text { Mean-12.0, } \\
\text { SD- } 2.9\end{array}$ & NR & NR & $p \leq 0.05$ & No change \\
\hline 23 & $\begin{array}{l}\text { Li et al. } \\
\text { [23] }\end{array}$ & China & $\begin{array}{l}\text { Retrospective } \\
\text { study }\end{array}$ & 22 & $\begin{array}{l}4 / \mathrm{M} \& \\
18 / \mathrm{F}\end{array}$ & $\begin{array}{l}\text { Mean-22.6 } \\
\quad \pm 4.5\end{array}$ & $\begin{array}{c}\text { Rapid } \\
\text { maxillary } \\
\text { expansion }\end{array}$ & NR & СВСТ & $\begin{array}{l}\text { Upper airway } \\
\text { of nasal } \\
\text { cavity, na- } \\
\text { sopharyngeal, } \\
\text { retropalatal, } \\
\text { retroglossal } \\
\text { and hypopha- } \\
\text { ryngeal } \\
\text { airway }\end{array}$ & $\begin{array}{c} \\
\text { Experimental: } \\
\text { Mean-27.8, } \\
\text { SD-10.8, } \\
\text { Control: } \\
\text { Mean-27.4, } \\
\text { SD-10 }\end{array}$ & NR & NR & $p \leq 0.05$ & Increase \\
\hline
\end{tabular}


Table A3. Cont.

\begin{tabular}{|c|c|c|c|c|c|c|c|c|c|c|c|c|c|c|c|}
\hline S.No & $\begin{array}{c}\text { Author \& } \\
\text { Year }\end{array}$ & Country & $\begin{array}{l}\text { Study } \\
\text { Design }\end{array}$ & $\begin{array}{l}\text { Sample } \\
\text { Size }\end{array}$ & Gender & $\begin{array}{l}\text { Age (Years) } \\
\text { Range/Mean/ } \\
\text { Median }\end{array}$ & Orthodontic & $\begin{array}{l}\text { Type of } \\
\text { Malocclu- } \\
\text { sion }\end{array}$ & $\begin{array}{l}\text { Method Used } \\
\text { to Assess the } \\
\text { Airway }\end{array}$ & $\begin{array}{c}\text { Specific } \\
\text { Airway } \\
\text { Space That } \\
\text { Was Assessed }\end{array}$ & Variables & $\begin{array}{c}\text { Actual } \\
\text { Baseline }\end{array}$ & $\begin{array}{c}\text { Follow up } \\
\text { Duration }\end{array}$ & $p$-Values & Outcome \\
\hline 24 & $\begin{array}{l}\text { De Sousa } \\
\text { Miranda } \\
\text { et al. [60] }\end{array}$ & Brazil & $\begin{array}{l}\text { Retrospective } \\
\text { study }\end{array}$ & 23 & $\begin{array}{l}8 / \mathrm{M} \& \\
15 / \mathrm{F}\end{array}$ & Mean-33 & $\begin{array}{l}\text { Class II } \\
\text { surgery }\end{array}$ & $\begin{array}{l}\text { Class II } \\
\text { malocclu- } \\
\text { sion }\end{array}$ & СВСТ & $\begin{array}{l}\text { Oropharyngeal } \\
\text { airway }\end{array}$ & $\begin{array}{l}\text { Surgery Class } \\
\text { II } \\
\text { Experimental: } \\
\text { Mean-20.4767 } \\
\text { Control: } \\
\text { Mean-30.5952 }\end{array}$ & NR & $\begin{array}{l}23 \text { patients } \\
\text { be } \\
\text { followed- } \\
\text { up at a } \\
\text { later date }\end{array}$ & $p \leq 0.05$ & Increase \\
\hline 25 & $\begin{array}{l}\text { Raffaini } \\
\text { et al. [61] }\end{array}$ & Italy & $\begin{array}{l}\text { Retrospective } \\
\text { study }\end{array}$ & 10 & $10 / \mathrm{F}$ & NR & $\begin{array}{l}\text { Class II } \\
\text { surgery }\end{array}$ & $\begin{array}{l}\text { Class II } \\
\text { malocclu- } \\
\text { sion }\end{array}$ & СВСТ & $\begin{array}{c}\text { Pharyngeal } \\
\text { airway }\end{array}$ & $\begin{array}{l}\text { Pre-surgical: } \\
\text { Mean-15.3, } \\
\text { SD-, } \\
\text { Post-surgical: } \\
\text { Mean-22.6, } \\
\text { SD- }\end{array}$ & NR & $\begin{array}{l}6 \text { to } 12 \\
\text { months } \\
\text { after } \\
\text { surgery }\end{array}$ & $p \leq 0.05$ & Increase \\
\hline 26 & $\begin{array}{l}\text { Gandedkar } \\
\text { et al. [49] }\end{array}$ & Singapore & $\begin{array}{l}\text { Retrospective } \\
\text { study }\end{array}$ & 58 & $\begin{array}{l}32 / \mathrm{F} \& \\
26 / \mathrm{M}\end{array}$ & $\begin{array}{l}\text { Mean-13.4 } \\
\quad \pm 0.5\end{array}$ & $\begin{array}{l}\text { Class III } \\
\text { surgery }\end{array}$ & $\begin{array}{l}\text { Class III } \\
\text { malocclu- } \\
\text { sion }\end{array}$ & СВСТ & $\begin{array}{c}\text { Pharyngeal } \\
\text { airway }\end{array}$ & $\begin{array}{l}\text { Pre-surgical: } \\
\text { Mean-27.7, } \\
\text { SD-1.2, } \\
\text { Post-surgical: } \\
\text { Mean-23.9, } \\
\text { SD-1.4 }\end{array}$ & NR & NR & $p \leq 0.05$ & Decrease \\
\hline 27 & $\begin{array}{l}\text { Fastuca } \\
\text { et al. [14] }\end{array}$ & Italy & $\begin{array}{l}\text { Retrospective } \\
\text { study }\end{array}$ & 15 & $\begin{array}{c}11 / \mathrm{F} \& \\
4 / \mathrm{M}\end{array}$ & $\begin{array}{c}\text { Mean-7.5 } \pm \\
0.3\end{array}$ & $\begin{array}{c}\text { Rapid } \\
\text { maxillary } \\
\text { expansion }\end{array}$ & NR & СВСТ & Nasal airway & $\begin{array}{c}\text { Maxillary } \\
\text { Expansion } \\
\text { Experimental: } \\
\text { Mean-17.0 } \\
\text { Control: } \\
\text { Mean- } 2.4\end{array}$ & NR & $\begin{array}{l}\text { Long term } \\
\text { follow-up }\end{array}$ & $p<0.001$ & No change \\
\hline 28 & $\begin{array}{l}\text { Al-Jewair } \\
\text { et al. [62] }\end{array}$ & USA & $\begin{array}{l}\text { Prospective } \\
\text { study }\end{array}$ & 8 & $5 / \mathrm{F} \& 3 / \mathrm{M}$ & Mean-44.6 & $\begin{array}{l}\text { Clear } \\
\text { aligner }\end{array}$ & $\begin{array}{l}\text { Class II } \\
\text { malocclu- } \\
\text { sion }\end{array}$ & СВСТ & $\begin{array}{l}\text { The upper } \\
\text { airway was } \\
\text { divided into } \\
\text { three regions: } \\
\text { the } \\
\text { nasopharynx } \\
\text { (NP), } \\
\text { oropharynx } \\
\text { (OP), and } \\
\text { hypopharynx } \\
\text { (HP). }\end{array}$ & $\begin{array}{l}\text { Clear aligner } \\
\text { Before } \\
\text { Treatment: } \\
\text { Mean-35.05, } \\
\text { SD-14.02 } \\
\text { After } \\
\text { Treatment: } \\
\text { Mean-32.24, } \\
\text { SD-9.16 }\end{array}$ & NR & NR & $p=0.250$ & Increase \\
\hline 29 & $\begin{array}{l}\text { Al-Jewair } \\
\text { et al. [62] }\end{array}$ & USA & $\begin{array}{l}\text { Retrospective } \\
\text { study }\end{array}$ & 24 & $\begin{array}{l}16 / \mathrm{F} \& \\
8 / \mathrm{M}\end{array}$ & $\begin{array}{c}\text { Mean- } \\
35.33 \pm \\
11.14\end{array}$ & $\begin{array}{l}\text { Clear } \\
\text { aligner }\end{array}$ & $\begin{array}{l}\text { Class III } \\
\text { malocclu- } \\
\text { sion }\end{array}$ & СВСТ & $\begin{array}{c}\text { Pharyngeal } \\
\text { airway }\end{array}$ & $\begin{array}{c}\text { Before: } \\
\text { Mean-13.6, } \\
\text { SD-4.02, } \\
\text { After: } \\
\text { Mean-12.07, } \\
\text { SD-3.65 }\end{array}$ & NR & NR & $p \leq 0.05$ & Decrease \\
\hline
\end{tabular}




\section{References}

1. Rasmus, R.L.; Jacobs, R.M. Mouth breathing and malocclusion: Quantitative technique for measurement of oral and nasal air-flow velocities. Angle Orthod. 1969, 39, 296-302. [CrossRef] [PubMed]

2. Mcnamara, J.R. Influence of respiratory pattern on craniofacial growth. Angle Orthod. 1981, 51, 269-300. [CrossRef]

3. Alrejaye, N.; Gao, J.; Hatcher, D.; Oberoi, S. Effect of maxillary expansion and protraction on the oropharyngeal airway in individuals with non-syndromic cleft palate with or without cleft lip. PLoS ONE 2019, 14, e90972. [CrossRef]

4. El, H.; Palomo, J.M. Three-dimensional evaluation of upper airway following rapid maxillary expansion A CBCT study. Angle Orthod. 2014, 84, 265-273. [CrossRef]

5. $\quad$ Ming, Y.; Hu, Y.; Li, Y.; Yu, J.; He, H.; Zheng, L. Effects of maxillary protraction appliances on airway dimensions in growing class III maxillary retrognathic patients: A systematic review and meta-analysis. Int. J. Pediatr. Otorhinolaryngol. 2018, 105, 138-145. [CrossRef] [PubMed]

6. $\quad \mathrm{Ng}$, J.H.; Song, Y.L.; Yap, A.U.J. Effects of bicuspid extractions and incisor retraction on upper airway of Asian adults and late adolescents: A systematic review. J. Oral Rehabil. 2019, 46, 1071-1087. [CrossRef] [PubMed]

7. Di Carlo, G.; Saccucci, M.; Ierardo, G.; Luzzi, V.; Occasi, F.; Zicari, A.M.; Duse, M.; Polimeni, A. Rapid Maxillary Expansion and Upper Airway Morphology: A Systematic Review on the Role of Cone Beam Computed Tomography. Biom Res. Int. 2017, 2017, 1-10. [CrossRef]

8. Niu, X.; Di Carlo, G.; Cornelis, M.A.; Cattaneo, P.M. Three-dimensional analyses of short- and long-term effects of rapid maxillary expansion on nasal cavity and upper airway: A systematic review and meta-analysis. Orthod. Craniofac. Res. 2020, 23, 250-276. [CrossRef] [PubMed]

9. Moher, D. Preferred Reporting Items for Systematic Reviews and Meta-Analyses: The PRISMA Statement. Ann. Intern. Med. 2009, 151, 264. [CrossRef] [PubMed]

10. Sterne, J.A.; Hernán, M.A.; Reeves, B.C.; Savović, J.; Berkman, N.D.; Viswanathan, M.; Henry, D.; Altman, D.G.; Ansari, M.T.; Boutron, I.; et al. ROBINS-I: A tool for assessing risk of bias in non-randomised studies of interventions. BMJ 2016, 355 , i4919. [CrossRef]

11. Pliska, B.T.; Tam, I.T.; Lowe, A.A.; Madson, A.M.; Almeida, F.R. Effect of orthodontic treatment on the upper airway volume in adults. Am. J. Orthod. Dentofac. Orthop. 2016, 150, 937-944. [CrossRef]

12. Zhang, J.; Chen, G.; Li, W.; Xu, T.; Gao, X. Upper airway changes after orthodontic extraction treatment in adults: A preliminary study using cone beam computed tomography. PLoS ONE 2015, 10, e0143233. [CrossRef]

13. Almuzian, M.; Ju, X.; Almukhtar, A.; Ayoub, A.; Al-Muzian, L.; McDonald, J.P. Does rapid maxillary expansion affect nasopharyngeal airway? A prospective Cone Beam Computerised Tomography (CBCT) based study. Surgeon 2018, 16, 1-11. [CrossRef] [PubMed]

14. Fastuca, R.; Perinetti, G.; Zecca, P.A.; Nucera, R.; Caprioglio, A. Airway compartments volume and oxygen saturation changes after rapid maxillary expansion: A longitudinal correlation study. Angle Orthod. 2015, 85, 955-961. [CrossRef] [PubMed]

15. Kim, S.Y.; Park, Y.C.; Lee, K.J.; Lintermann, A.; Han, S.S.; Yu, H.S.; Choi, Y.J. Assessment of changes in the nasal airway after nonsurgical miniscrew-assisted rapid maxillary expansion in young adults. Angle Orthod. 2018, 88, 435-441. [CrossRef] [PubMed]

16. Concato, J.; Shah, N.; Horwitz, R.I. Randomized, Controlled Trials, Observational Studies, and the Hierarchy of Research Designs. N. Engl. J. Med. 2000, 342, 1887-1892. [CrossRef]

17. Aboudara, C.; Nielsen, I.; Huang, J.C.; Maki, K.; Miller, A.J.; Hatcher, D. Comparison of airway space with conventional lateral headfilms and 3-dimensional reconstruction from cone-beam computed tomography. Am. J. Orthod. Dentofac. Orthop. 2009, 135, 468-479. [CrossRef] [PubMed]

18. Schütz-Fransson, U.; Kurol, J. Rapid Maxillary Expansion Effects on Nocturnal Enuresis in Children. Angle Orthod. 2008, 78, 201-208. [CrossRef] [PubMed]

19. Gray, L.P. Rapid maxillary expansion and impaired nasal respiration. Ear Nose Throat J. 1987, 66, $248-251$.

20. Camacho, M.; Chang, E.T.; Song, S.A.; Abdullatif, J.; Zaghi, S.; Pirelli, P.; Certal, V.; Guilleminault, C. Rapid maxillary expansion for pediatric obstructive sleep apnea: A systematic review and meta-analysis. Laryngoscope 2017, 127, 1712-1719. [CrossRef]

21. Abdalla, Y.; Brown, L.; Sonnesen, L. Effects of rapid maxillary expansion on upper airway volume: A three-dimensional cone-beam computed tomography study. Angle Orthod. 2019, 89, 917-923. [CrossRef]

22. Zeng, J.; Gao, X. A prospective CBCT study of upper airway changes after rapid maxillary expansion. Int. J. Pediatr. Otorhinolaryngol. 2013, 77, 1805-1810. [CrossRef]

23. Li, Q.; Tang, H.; Liu, X.; Luo, Q.; Jiang, Z.; Martin, D.; Guo, J. Comparison of dimensions and volume of upper airway before and after mini-implant assisted rapid maxillary expansion. Angle Orthod. 2020, 90, 432-441. [CrossRef]

24. Pirelli, P.; Saponara, M.; Guilleminault, C. Rapid maxillary expansion (RME) for pediatric obstructive sleep apnea: A 12-year follow-up. Sleep Med. 2015, 16, 933-935. [CrossRef] [PubMed]

25. Ngan, P.W.; Hagg, U.; Yiu, C.; Wei, S.H.Y. Treatment response and long-term dentofacial adaptations to maxillary expansion and protraction. Semin. Orthod. 1997, 3, 255-264. [CrossRef]

26. Fu, Z.; Lin, Y.; Ma, L.; Li, W. Effects of maxillary protraction therapy on the pharyngeal airway in patients with repaired unilateral cleft lip and palate: A 3-dimensional computed tomographic study. Am. J. Orthod. Dentofac. Orthop. 2016, 149, 673-682. [CrossRef] [PubMed] 
27. Jia, H.; Li, W.; Lin, J. Maxillary protraction effects on anterior crossbites: Repaired unilateral cleft versus noncleft prepubertal boys. Angle Orthod. 2008, 78, 617-624. [CrossRef]

28. Sharma, J.N. Skeletal and Soft Tissue Point A and B Changes Following Orthodontic Treatment of Nepalese Class I Bimaxillary Protrusive Patients. Angle Orthod. 2010, 80, 91-96. [CrossRef]

29. Stefanovic, N.; El, H.; Chenin, D.L.; Glisic, B.; Palomo, J.M. Three-dimensional pharyngeal airway changes in orthodontic patients treated with and without extractions. Orthod. Craniofacial Res. 2013, 16, 87-96. [CrossRef]

30. Valiathan, M.; El, H.; Hans, M.G.; Palomo, M.J. Effects of extraction versus non-extraction treatment on oropharyngeal airway volume. Angle Orthod. 2010, 80, 1068-1074. [CrossRef] [PubMed]

31. Chiang, C.C.; Jeffres, M.N.; Miller, A.; Hatcher, D.C. Three-dimensional airway evaluation in 387 subjects from one university orthodontic clinic using cone beam computed tomography. Angle Orthod. 2012, 82, 985-992. [CrossRef]

32. Chen, Y.; Hong, L.; Wang, C.; Zhang, S.; Cao, C.; Wei, F.; Lv, T.; Zhang, F.; Liu, D. Effect of large incisor retraction on upper airway morphology in adult bimaxillary protrusion patients. Angle Orthod. 2012, 82, 964-970. [CrossRef] [PubMed]

33. Wang, Q.; Jia, P.; Anderson, N.K.; Wang, L.; Lin, J. Changes of pharyngeal airway size and hyoid bone position following orthodontic treatment of Class I bimaxillary protrusion. Angle Orthod. 2012, 82, 115-121. [CrossRef] [PubMed]

34. Miles, P.G.; Vig, P.S.; Weyant, R.J.; Forrest, T.D.; Rockette, H.E. Craniofacial structure and obstructive sleep apnea syndrome-a qualitative analysis and meta-analysis of the literature. Am. J. Orthod. Dentofac. Orthop. 1996, 109, 163-172. [CrossRef]

35. Lowe, A.A.; Santamaria, J.D.; Fleetham, J.A.; Price, C. Facial morphology and obstructive sleep apnea. Am. J. Orthod. Dentofac. Orthop. 1986, 90, 484-491. [CrossRef]

36. Restrepo, C.; Santamaría, A.; Peláez, S.; Tapias, A. Oropharyngeal airway dimensions after treatment with functional appliances in class II retrognathic children. J. Oral Rehabil. 2011, 38, 588-594. [CrossRef] [PubMed]

37. Koretsi, V.; Zymperdikas, V.F.; Papageorgiou, S.N.; Papadopoulos, M.A. Treatment effects of removable functional appliances in patients with Class II malocclusion: A systematic review and meta-analysis. Eur. J. Orthod. 2015, 37, 418-434. [CrossRef] [PubMed]

38. Zymperdikas, V.F.; Koretsi, V.; Papageorgiou, S.N.; Papadopoulos, M.A. Treatment effects of fixed functional appliances in patients with Class II malocclusion: A systematic review and meta-analysis. Eur. J. Orthod. 2016, 38, 113-126. [CrossRef]

39. Oliveira, P.M.; Cheib-Vilefort, P.L.; de Pársia Gontijo, H.; Melgaço, C.A.; Franchi, L.; McNamara, J.A.; Souki, B.Q. Threedimensional changes of the upper airway in patients with Class II malocclusion treated with the Herbst appliance: A cone-beam computed tomography study. Am. J. Orthod. Dentofac. Orthop. 2020, 157, 205-211. [CrossRef]

40. Temani, P.; Jain, P.; Rathee, P.; Temani, R. Volumetric changes in pharyngeal airway in Class II division 1 patients treated with Forsus-fixed functional appliance: A three-dimensional cone-beam computed tomography study. Contemp. Clin. Dent. 2016, 7, 31-35. [CrossRef]

41. Alhammadi, M.S.; Elfeky, H.Y.; Fayed, M.S.; Ishaq, R.A.R.; Halboub, E.; Al-mashraqi, A.A. Three-dimensional skeletal and pharyngeal airway changes following therapy with functional appliances in growing skeletal Class II malocclusion patients: A controlled clinical trial. J. Orofac. Orthop. 2019, 80, 254-265. [CrossRef]

42. Xiang, M.; Hu, B.; Liu, Y.; Sun, J.; Song, J. Changes in airway dimensions following functional appliances in growing patients with skeletal class II malocclusion: A systematic review and meta-analysis. Int. J. Pediatr. Otorhinolaryngol. 2017, 97, 170-180. [CrossRef] [PubMed]

43. Padmanabhan, S. Effect of functional appliances on the airway in Class II malocclusions. J. World Fed. Orthod. 2020, 9, S27-S30. [CrossRef] [PubMed]

44. Kim, Y.-J.; Hong, J.-S.; Hwang, Y.-I.; Park, Y.-H. Three-dimensional analysis of pharyngeal airway in preadolescent children with different anteroposterior skeletal patterns. Am. J. Orthod. Dentofac. Orthop. 2010, 137, 306.e1-306.e11. [CrossRef] [PubMed]

45. El, H.; Palomo, J.M. An airway study of different maxillary and mandibular sagittal positions. Eur. J. Orthod. 2013, 35, 262-270. [CrossRef]

46. Jakobsone, G.; Neimane, L.; Krumina, G. Two- and three-dimensional evaluation of the upper airway after bimaxillary correction of Class III malocclusion. Oral Surgery Oral Med. Oral Pathol. Oral Radiol. Endodontol. 2010, 110, 234-242. [CrossRef]

47. Chen, F.; Terada, K.; Hua, Y.; Saito, I. Effects of bimaxillary surgery and mandibular setback surgery on pharyngeal airway measurements in patients with Class III skeletal deformities. Am. J. Orthod. Dentofac. Orthop. 2007, 131, 372-377. [CrossRef]

48. da Silva Machado, V.; Cantharino de Carvalho, B.A.; Vedovello, S.A.S.; Valdrighi, H.; Santamaria Júnior, M. Pharyngeal Airway Modifications in Skeletal Class III Patients Undergoing Bimaxillary Advancement Surgery. J. Oral Maxillofac. Surg. 2019, 77, 2126.e1-2126.e8. [CrossRef] [PubMed]

49. Gandedkar, N.H.; Chng, C.K.; Basheer, M.A.; Chen, P.Y.; Yeow, V.K.L. Comparative evaluation of the pharyngeal airway space in unilateral and bilateral cleft lip and palate individuals with noncleft individuals: A cone beam computed tomography study. Cleft Palate-Craniofac. J. 2017, 54, 509-516. [CrossRef] [PubMed]

50. Christovam, I.O.; Lisboa, C.O.; Ferreira, D.M.T.P.; Cury-Saramago, A.A.; Mattos, C.T. Upper airway dimensions in patients undergoing orthognathic surgery: A systematic review and meta-analysis. Int. J. Oral Maxillofac. Surg. 2016, 45, 460-471. [CrossRef]

51. Giralt-Hernando, M.; Valls-Ontañón, A.; Guijarro-Martínez, R.; Masià-Gridilla, J.; Hernández-Alfaro, F. Impact of surgical maxillomandibular advancement upon pharyngeal airway volume and the apnoea-hypopnoea index in the treatment of obstructive sleep apnoea: Systematic review and meta-analysis. BMJ Open Respir. Res. 2019, 6, e000402. [CrossRef] [PubMed] 
52. Ingman, T. Cephalometric comparison of pharyngeal changes in subjects with upper airway resistance syndrome or obstructive sleep apnoea in upright and supine positions. Eur. J. Orthod. 2004, 26, 321-326. [CrossRef] [PubMed]

53. Joy, A.; Park, J.; Chambers, D.W.; Oh, H. Airway and cephalometric changes in adult orthodontic patients after premolar extractions. Angle Orthod. 2020, 90, 39-46. [CrossRef] [PubMed]

54. Yuen, H.; Rossouw, P.E.; Wolford, L.M.; Wang, H. Pharyngeal Airway Space Changes After Condylar Replacement and Mandibular Advancement Surgery. J. Oral Maxillofac. Surg. 2018, 76, 1165-1174. [CrossRef] [PubMed]

55. Chen, X.; Liu, D.; Liu, J.; Wu, Z.; Xie, Y.; Li, L.; Liu, H.; Guo, T.; Chen, C.; Zhang, S. Three-dimensional evaluation of the upper airway morphological changes in growing patients with skeletal class III malocclusion treated by protraction headgear and rapid palatal expansion: A comparative research. PLoS ONE 2015, 10, e0135273. [CrossRef] [PubMed]

56. Nguyen, T.; De Clerck, H.; Wilson, M.; Golden, B. Effect of class III bone anchor treatment on airway. Angle Orthod. 2015, 85, 591-596. [CrossRef]

57. Yilmaz, B.S.; Kucukkeles, N. Skeletal, soft tissue, and airway changes following the alternate maxillary expansions and constrictions protocol. Angle Orthod. 2015, 85, 117-126. [CrossRef]

58. Pamporakis, P.; Nevzatoğlu, Ş.; Küçükkeleş, N. Three-dimensional alterations in pharyngeal airway and maxillary sinus volumes in Class III maxillary deficiency subjects undergoing orthopedic facemask treatment. Angle Orthod. 2014, 84, 701-707. [CrossRef] [PubMed]

59. Hong, J.S.; Oh, K.M.; Kim, B.R.; Kim, Y.J.; Park, Y.H. Three-dimensional analysis of pharyngeal airway volume in adults with anterior position of the mandible. Am. J. Orthod. Dentofac. Orthop. 2011, 140, e161-e169. [CrossRef]

60. De Sousa Miranda, W.; Álvares De Castro Rocha, V.; Lara Dos Santos Marques, K.; Trindade Neto, A.I.; Do Prado, C.J.; ZanettaBarbosa, D. Three-dimensional evaluation of superior airway space after orthognathic surgery with counterclockwise rotation and advancement of the maxillomandibular complex in Class II patients. Oral Surg. Oral Med. Oral Pathol. Oral Radiol. 2015, 120, 453-458. [CrossRef] [PubMed]

61. Raffaini, M.; Pisani, C. Clinical and cone-beam computed tomography evaluation of the three-dimensional increase in pharyngeal airway space following maxillo-mandibular rotation-advancement for Class II-correction in patients without sleep apnoea (OSA) J. Cranio-Maxillof. Surg. 2013, 41, 552-557. [CrossRef] [PubMed]

62. Al-Jewair, T.; Kurtzner, K.; Giangreco, T.; Warunek, S.; Lagravère-Vich, M. Effects of clear aligner therapy for Class II malocclusion on upper airway morphology and daytime sleepiness in adults: A case series. Int. Orthod. 2020, 18, 154-164. [CrossRef] [PubMed] 